\title{
Activated carbon obtained from sapelli wood sawdust by microwave heating for $o$-cresol adsorption
}

\author{
Pascal S. Thue ${ }^{1,2}$ - Glaydson S. dos Reis ${ }^{1,3}$ (D) \\ Eder C. Lima ${ }^{1} \cdot$ Joseph M. Sieliechi ${ }^{2}$. \\ G. L. Dotto ${ }^{4}$ Alfred G. N. Wamba ${ }^{1,5}$. \\ Silvio L. P. Dias ${ }^{1} \cdot$ Flavio A. Pavan 6
}

Received: 29 April 2016/Accepted: 28 July 2016/Published online: 6 August 2016

(C) Springer Science+Business Media Dordrecht 2016

\begin{abstract}
Activated carbon (AC) was prepared from sapelli wood sawdust using a microwave heating process. The biomass was mixed with inorganic components (lime $+\mathrm{ZnCl}_{2}$ and $\mathrm{FeCl}_{3}$ ) to form a homogeneous paste. The $\mathrm{AC}$ samples are denoted as AC-1A (100 g sapelli wood sawdust $+20 \mathrm{~g}$ lime $+80 \mathrm{~g} \mathrm{ZnCl}$ ), AC2A (150 g sapelli wood sawdust $+20 \mathrm{~g}$ lime $\left.+80 \mathrm{~g} \mathrm{ZnCl}_{2}\right)$, AC-1B (100 g sapelli wood sawdust $+20 \mathrm{~g}$ lime $+40 \mathrm{~g} \mathrm{ZnCl} 2+40 \mathrm{~g} \mathrm{FeCl}$ ), and $\mathrm{AC}-2 \mathrm{~B}$ (150 g sapelli wood sawdust $+20 \mathrm{~g}$ lime $+40 \mathrm{~g} \mathrm{ZnCl}_{2}+40 \mathrm{~g} \mathrm{FeCl}_{3}$ ). The samples were placed in a microwave oven and pyrolyzed under nitrogen flow. To increase their porosity, the pyrolyzed samples were subjected to a leaching process (with $6 \mathrm{~mol} \mathrm{~L}{ }^{-1} \mathrm{HCl}$ ) under reflux to eliminate inorganic components. Several analytical techniques such as Fourier-transform infrared (FTIR) spectroscopy, scanning electron microscopy (SEM), and $\mathrm{N}_{2}$ isotherm and vapor adsorption analyses were performed to characterize the AC materials. The samples presented high Brunauer-
\end{abstract}

Electronic supplementary material The online version of this article (doi:10.1007/s11164-016-2683-8) contains supplementary material, which is available to authorized users.

Glaydson S. dos Reis

glaydson.simoes@ufrgs.br

1 Institute of Chemistry, Federal University of Rio Grande do Sul (UFRGS), Av. Bento Gonçalves 9500, P.O. Box 15003, Porto Alegre, RS 91501-970, Brazil

2 Department of Applied Chemistry, University of Ngaoundere, P.O. Box 455, Ngaoundere, Cameroon

3 Department of Metallurgy, Federal University of Rio Grande do Sul (UFRGS), Av. Bento Gonçalves, 9500, Porto Alegre, Brazil

4 Department of Chemical Engineering, Federal University of Santa Maria (UFSM), Santa Maria, RS, Brazil

5 Department of Process Engineering, University of Ngaoundere, Ngaoundere, Cameroon

6 Federal University of Pampa (UNIPAMPA), Bagé, RS, Brazil 
Emmett-Teller (BET) surface areas, up to $941.08 \mathrm{~m}^{2} \mathrm{~g}^{-1}$ for AC-1A. The AC materials were tested for their $o$-cresol removal ability by determining the best fits to equilibrium and kinetic data using the Sips isotherm and fractional-order model, respectively. The maximum adsorption capacity of the AC samples as obtained from the Sips model was correlated with the surface area. The proposed adsorption mechanism suggests that hydrogen bonding, donor-acceptor complexation, and $\pi-\pi$ interactions play key roles. The adsorbents were also tested for treatment of simulated industrial effluents, showing very good efficiency. Almost complete regeneration of the $\mathrm{AC}$ adsorbents was achieved using $10 \% \mathrm{EtOH}+5 \mathrm{~mol} \mathrm{~L}^{-1} \mathrm{NaOH}$ as eluent. These results demonstrate that sapelli wood sawdust is a promising precursor for preparation of AC to remove $o$-cresol from aqueous solution.

Keywords Activated carbon - Microwave-assisted pyrolysis $\cdot o$-Cresol $\cdot$ Kinetic models

\section{Introduction}

Phenols are pollutants whose presence at even low concentration can seriously impact on water use and reuse. Phenols are commonly found in wastewater generated from petrochemical, steel, and phenol-producing industries as well as coal conversion [1].

Many phenols are hazardous contaminants because of their toxicity to the environment and living beings [2, 3]. Ingestion of water contaminated with high phenol content can cause serious gastrointestinal damage, muscle tremors, difficulty in walking, and death in animals [1, 3]. Therefore, Environmental Protection Agency (EPA) regulations try to lower the phenol content in wastewater to below $1 \mu \mathrm{g} \mathrm{mL}^{-1}$ [4]. Because of this high toxicity, effluents containing phenols must be treated before being disposal in the environment.

Additionally, it is well known that conventional wastewater and drinking-water treatment processes are not very efficient for removal of such phenolic compound pollutants. Therefore, study of effective methods for removing phenols from water and/or wastewater has become urgent.

There are many techniques for treatment of wastewater contaminated with phenolic compounds, including biological processes [5, 6], coagulation [7], membranes [8], electro-Fenton and photoelectro-Fenton treatments [9], ozonation [10], oxidation [11, 12], and adsorption [13-16]. However, application of these methods is restricted since they are very expensive and involve high initial capital and operational costs. On the other hand, adsorption is a more attractive method because pollutants can be removed from aqueous effluent while the adsorbent can be reused several times, making the wastewater treatment process economically feasible.

The most well-known and commonly used adsorbent is activated carbon (AC), especially for removal of organic hazards [16-18], due to its good textural features such as high surface area and pore volume [16-18]. 
In recent years, researchers have studied various different kinds of precursor for preparation of activated carbon, including sewage sludge [17, 18], agroindustrial waste [16, 19], tire waste [20], cotton seed cake [21], biomass from wood [22], etc.

Chips and sawdust are waste biomass from wood processing. A study in 28 sawmills in the City of Ngaoundere, Cameroon revealed very high use of lignocellulosic wood species (3.120 tons per year) such as ayous and sapelli. Transformation of these species generates tons of waste per year [23]. Therefore, any attempt to reuse this waste would be useful for the country [24].

Preparation of activated carbon can be accomplished using a conventional furnace or a microwave oven $[17,25]$. The main difference between these two types of pyrolysis is the way in which the heat is generated. Transfer of heat occurs by conduction in a conventional oven, unlike in microwave heating, where the energy is furnished directly to the carbon bed, being transformed into heat inside the sample by ionic conduction and dipole rotation through friction within the material [17, 25, 26]. Microwave heating is advantageous because of its shorter pyrolysis time ( $<10 \mathrm{~min})$ [27] for activation as a result of the rapid temperature rise, as well as its remarkably lower energy consumption [25-27].

The aim of this work is to produce different AC materials using microwaveassisted pyrolysis and test these adsorbents for $o$-cresol removal from aqueous solution. The effect of different operational parameters, such as temperature and the initial $\mathrm{pH}$ value of the $o$-cresol solution, on the batch adsorption system was verified. Several analytical techniques were used to explore the nature of the AC samples obtained with regard to their structure and surface texture.

\section{Experimental}

\section{Chemicals and reagents}

$o$-Cresol (see Supplementary Fig. 1) was supplied by Vetec (São Paulo, Brazil). $\mathrm{ZnCl}_{2}$ and $\mathrm{FeCl}_{3}$ were purchased from Synth (Diadema, SP, Brazil). Analytical reagent grade of $99 \%$ purity was employed throughout the experiments. Lime $\left[\mathrm{CaCO}_{3}+\right.$ $\mathrm{Ca}(\mathrm{OH})_{2}+\mathrm{CaO}$ ] was obtained from Votoratim (Canoas, RS, Brazil). Lime is used as one of the inorganic components in preparation of activated carbon to avoid impregnation of the carbonaceous material with aqueous solution [28]. In the presence of water, lime forms a paste that holds all the solid constituents together [28].

The reagents $o$-nitrophenol, 2-naphthol, $o$-chlorophenol, $p$-nitrophenol, hydroquinone, resorcinol, $m$-cresol, bisphenol A, phenol, humic acid, sodium sulfate, sodium chloride, potassium phosphate, sodium carbonate, potassium nitrate, sodium hydroxide, and hydrochloric acid for preparation of simulated industrial effluents were purchased from Vetec (São Paulo, Brazil).

\section{Preparation of AC adsorbents}

AC adsorbents were prepared using the following procedure: 100.0 or $150.0 \mathrm{~g}$ of powdered sapelli wood sawdust (diameter $<250 \mu \mathrm{m}$ ) and $100.0 \mathrm{~g}$ of inorganic 
components (20 g lime $+80 \mathrm{~g} \mathrm{ZnCl}_{2}$ or $20 \mathrm{~g}$ lime $+40 \mathrm{~g} \mathrm{ZnCl} 2+40 \mathrm{~g} \mathrm{FeCl}_{3}$ ) and $45.0 \mathrm{~mL} \mathrm{H}_{2} \mathrm{O}$ were added and mixed thoroughly to produce a uniform mixture [28]. Before the pyrolysis step, the mixture was oven-dried at $90{ }^{\circ} \mathrm{C}$ for $120 \mathrm{~min}$. Thereafter, $30.0 \mathrm{~g}$ of sample was placed in a quartz reactor that was inserted into a microwave oven under inert atmosphere $\left(200 \mathrm{~mL} \mathrm{~min}^{-1}\right.$ nitrogen $)$ [27]. The microwave was turned on for $320 \mathrm{~s}$ at $1200 \mathrm{~W}$, then sat for $10 \mathrm{~min}$ for the system to cool down [27]. The material obtained after pyrolysis was named according to the composition of the activating agent and constituent ratios as follows: $1 \mathrm{~A}(100 \mathrm{~g}$ sapelli wood sawdust $+20 \mathrm{~g}$ lime $\left.+80 \mathrm{~g} \mathrm{ZnCl}_{2}\right)$, 2A (150 g sapelli wood sawdust $\left.+20 \mathrm{~g} \mathrm{lime}+80 \mathrm{~g} \mathrm{ZnCl}_{2}\right)$, $1 \mathrm{~B}(100 \mathrm{~g}$ sapelli wood sawdust $+20 \mathrm{~g}$ lime $+40 \mathrm{~g} \mathrm{ZnCl}_{2}+40 \mathrm{~g} \mathrm{FeCl}_{3}$ ), and 2B (150 g sapelli wood sawdust $+20 \mathrm{~g}$ lime $+40 \mathrm{~g} \mathrm{ZnCl}_{2}+40 \mathrm{~g} \mathrm{FeCl}_{3}$ ).

To complete chemical activation, a leaching procedure was performed to eliminate remaining inorganic compounds $\left(\mathrm{ZnCl}_{2}\right.$ and $\left.\mathrm{FeCl}_{3}\right)$ from the carbonized materials using $6.0 \mathrm{~mol} \mathrm{~L}{ }^{-1} \mathrm{HCl}$ under reflux, as already described in literature $[27,28]$. The carbonized materials $1 \mathrm{~A}, 2 \mathrm{~A}, 1 \mathrm{~B}$, and $2 \mathrm{~B}$ gave rise to $\mathrm{AC}-1 \mathrm{~A}, \mathrm{AC}-2 \mathrm{~A}$, $\mathrm{AC}-1 \mathrm{~B}$, and $\mathrm{AC}-2 \mathrm{~B}$, respectively, after acidic leaching of inorganic contents.

\section{Characterization of AC samples}

The AC samples were ground and sieved for $\mathrm{N}_{2}$ adsorption-desorption isotherm analysis. The resulting fine $(<53 \mu \mathrm{m})$ powder was used for adsorption experiments with a commercial system (TriStar II 3020; Micromeritics Instrument Corp.) at $-196{ }^{\circ} \mathrm{C}$ after drying for $24 \mathrm{~h}$ at $150{ }^{\circ} \mathrm{C}$ under reduced pressure $(<2$ mbar $)$. The surface area and pore size distribution of the $\mathrm{AC}$ samples were determined by the Brunauer-Emmett-Teller (BET) multipoint and Barrett-Joyner-Halenda (BJH) technique, respectively [29].

The surface of the AC samples was analyzed by scanning electron microscopy (SEM, JSM 6060; JEOL).

To determine their surface hydrophobicity/hydrophilicity, the AC samples were dried in $10-\mathrm{mL}$ beakers at $70{ }^{\circ} \mathrm{C}$ for $24 \mathrm{~h}$. The samples were then transferred to a desiccator and cooled to room temperature, then the accurate weight (ca. $0.3 \mathrm{~g}$ ) of each sample was obtained. Afterwards, the beakers were arranged in capped (45/ $50 \mathrm{~mm}$ joint) Erlenmeyer flasks containing $60 \mathrm{~mL}$ solvent (water and $n$-heptane) inside a temperature-regulated shaker at $25{ }^{\circ} \mathrm{C}$ in static condition, in such a way that the glass containing the samples was not in contact with the solvent or wall of the Erlenmeyer flask. After $24 \mathrm{~h}$, the sample was removed from the Erlenmeyer flask, dried carefully on the outside with laboratory tissues, and weighed again. The maximal amount of vapor adsorbed on the activated carbon was obtained as the difference between the final and initial weight, expressed in $\mathrm{mg} \mathrm{g}^{-1}$. The hydrophilic/hydrophobic properties were determined from the ratio of adsorbed $n$-heptane vapor $\left(\mathrm{mg} \mathrm{g}^{-1}\right)$ to adsorbed water vapor $\left(\mathrm{mg} \mathrm{g}^{-1}\right)$.

The $\mathrm{pH}_{\mathrm{pzc}}$ values were obtained using a procedure described in literature [30].

The total acidity and basicity of the AC samples were determined using a modified Boehm titration method [31]. 


\section{Adsorption studies}

$o$-Cresol solution $(20.00 \mathrm{~mL})$ with concentration ranging from 5.00 to $500.0 \mathrm{mg} \mathrm{L}^{-1}$ was added to $50.0-\mathrm{mL}$ flat Falcon tubes containing $30 \mathrm{mg}$ of each $\mathrm{AC}$ sample at $\mathrm{pH}$ values ranging from 4.0 to 10.0. The tubes were capped, then arranged horizontally inside a temperature-controlled shaker. The mixtures were shaken at speed of $150 \mathrm{rpm}$ for between 1 and $120 \mathrm{~min}$ at 25 to $50{ }^{\circ} \mathrm{C}$. Afterwards, the samples were centrifuged in a UniCen M centrifuge (Herolab) to separate the AC from the liquid phase, and $1-5 \mathrm{~mL}$ of supernatant was diluted to $10.0-50.0 \mathrm{~mL}$ in calibrated flasks using blank solution (aqueous solution with $\mathrm{pH}$ 4.0-10.0). After the batch adsorption experiment, the unadsorbed $o$-cresol was measured using a T90+ spectrophotometer (PG Instruments) at a maximum wavelength of $269 \mathrm{~nm}$.

The sorption capacity for and percentage removal of $o$-cresol were calculated using Eqs. (1) and (2), respectively:

$$
\begin{gathered}
q=\frac{\left(C_{0}-C_{\mathrm{f}}\right)}{m} \times V, \\
\% \text { Removal }=100 \times \frac{\left(C_{0}-C_{\mathrm{f}}\right)}{C_{0}},
\end{gathered}
$$

where $q$ is the sorption capacity of the adsorbent for $o$-cresol $\left(\mathrm{mg} \mathrm{g}^{-1}\right), C_{0}$ is the initial $o$-cresol concentration in contact with the $\mathrm{AC}\left(\mathrm{mg} \mathrm{L}^{-1}\right), C_{\mathrm{f}}$ is the $o$-cresol concentration in equilibrium $\left(\mathrm{mg} \mathrm{L}^{-1}\right), m$ is the weight of $\mathrm{AC}(\mathrm{g})$, and $V$ is the volume of $o$-cresol solution (L).

\section{Analytical control and statistical evaluation of nonlinear methods}

To guarantee reliability, accuracy, and reproducibility of adsorption data, adsorption experiments were performed thrice [32]. The $o$-cresol solutions were placed in glass bottles which had been cleaned by submerging in $10 \% \mathrm{HNO}_{3}$ overnight [33], washing with distilled water, drying in a oven at $70{ }^{\circ} \mathrm{C}$, and storing [34].

Standard $o$-cresol solutions $\left(100.0-300.0 \mathrm{mg} \mathrm{L}^{-1}\right)$ were used to determined analytical calibration curves. The detection limit of $o$-cresol was $0.030 \mathrm{mg} \mathrm{L}^{-1}$ [35].

Fitting of kinetic and equilibrium data was performed using nonlinear methods (simplex method and Levenberg-Marquardt algorithm) in Origin 2015 software (Microcal). The suitability of the nonlinear models was evaluated using the coefficient of determination $\left(R^{2}\right)$, adjusted coefficient of determination $\left(R_{\text {adj }}^{2}\right)$, and standard deviation of residues (SD) [36, 37], as given by Eqs. (3), (4), and (5), respectively:

$$
R^{2}=\left(\frac{\sum_{i}^{n}\left(q_{i, \exp }-\bar{q}_{i, \exp }\right)^{2}-\sum_{i}^{n}\left(q_{i, \exp }-q_{i, \text { model }}\right)^{2}}{\sum_{i}^{n}\left(q_{i, \exp }-\bar{q}_{i, \exp }\right)^{2}}\right),
$$




$$
\begin{gathered}
R_{\mathrm{adj}}^{2}=1-\left(1-R^{2}\right) \cdot\left(\frac{n-1}{n-p-1}\right), \\
\mathrm{SD}=\sqrt{\left(\frac{1}{n-p}\right) \cdot \sum_{i}^{n}\left(q_{i, \exp }-q_{i, \text { model }}\right)^{2}},
\end{gathered}
$$

where $q_{i \text {, model }}$ is each individual $q$ value predicted by the model, $q_{i, \text { exp }}$ is each individual experimental $q$ value, $\bar{q}_{\text {exp }}$ is the average of all experimental $q$ values, $n$ is the number of experiments performed, and $p$ is the number of parameters in the model [36, 37].

\section{Adsorption kinetics}

Kinetic data were fit using pseudo-first-order, pseudo-second-order, and Avrami fractional-order models, as given by the mathematical Eqs. (6), (7), and (8), respectively [36, 37]:

$$
\begin{gathered}
q_{t}=q_{\mathrm{e}} \cdot\left[1-\exp \left(-k_{1} \cdot t\right)\right], \\
q_{t}=q_{\mathrm{e}}-\frac{q_{\mathrm{e}}}{\left[k_{2}\left(q_{\mathrm{e}}\right) \cdot t+1\right]}, \\
q_{t}=q_{\mathrm{e}} \cdot\left\{1-\exp \left[-\left(k_{\mathrm{AV}} \cdot t\right)\right]^{n_{\mathrm{AV}}}\right\} .
\end{gathered}
$$

\section{Adsorption equilibrium}

The experimental equilibrium data were fit using the Langmuir, Freundlich, and Sips isotherm models, as represented by Eqs. (9), (10), and (11), respectively $[36,37]$ :

$$
\begin{gathered}
q_{\mathrm{e}}=\frac{Q_{\mathrm{max}} \cdot K_{\mathrm{L}} \cdot C_{\mathrm{e}}}{1+K_{\mathrm{L}} \cdot C_{\mathrm{e}}}, \\
q_{\mathrm{e}}=K_{\mathrm{F}} \cdot C_{\mathrm{e}}^{1 / n_{\mathrm{F}}}, \\
q_{\mathrm{e}}=\frac{Q_{\max } \cdot K_{\mathrm{s}} \cdot C_{\mathrm{e}}^{1 / n_{\mathrm{s}}}}{1+K_{\mathrm{s}} \cdot C_{\mathrm{e}}^{1 / n_{\mathrm{s}}}} .
\end{gathered}
$$

\section{Synthetic effluents}

Two synthetic industrial effluents, consisting of a mixture of ten phenols, humic acid, and inorganics usually present in industrial effluents, were prepared. The compositions of the effluents are presented in Table 1 . The aim of using synthetic effluents is to test the sorption capacity of the AC samples for removal of a mixture 
Table 1 Chemical composition of simulated industrial effluents

\begin{tabular}{lcc}
\hline Phenols & \multicolumn{2}{l}{ Concentration $\left(\mathrm{mg} \mathrm{L}^{-1}\right)$} \\
\cline { 2 - 3 } & Effluent A & Effluent B \\
\hline$o$-Cresol & 50.0 & 60.0 \\
Phenol & 10.0 & 15.0 \\
m-Cresol & 5.00 & 10.0 \\
2-Chlorophenol & 5.00 & 10.0 \\
Bisphenol A & 5.00 & 10.0 \\
2-Nitrophenol & 5.00 & 10.0 \\
4-Nitrophenol & 5.00 & 10.0 \\
2-Naphthol & 5.00 & 10.0 \\
Hydroquinone & 5.00 & 10.0 \\
Resorcinol & 5.00 & 10.0 \\
Other organic component & & \\
Humic acid & 10.0 & 20.0 \\
Inorganic components & & \\
Sodium sulfate & 40.0 & 40.0 \\
Sodium carbonate & 20.0 & 40.0 \\
Sodium chloride & 20.0 & 40.0 \\
Potassium nitrate & 20.0 & 40.0 \\
Potassium phosphate & 21.0 & 36.4 \\
pH & 7.0 & 7.0 \\
& &
\end{tabular}

of phenolic compounds from a solution containing high concentrations of organic matter and salts.

\section{Results and discussion}

\section{Characterization of activated carbon samples}

The chemical activation of the sapelli wood with inorganics and further pyrolysis assisted by microwaves generated different activated carbon materials with different adsorption characteristics. Among the main features of the adsorbents, the surface area and porosity have the greatest influence on the adsorption process. $\mathrm{N}_{2}$ adsorption-desorption isotherms and $\mathrm{BJH}$ plots for samples $\mathrm{AC}-1 \mathrm{~A}, \mathrm{AC}-1 \mathrm{~B}, \mathrm{AC}-$ 2A, and AC-2B are presented in Fig. 1.

The nitrogen isotherms for the activated carbon materials are shown in Fig. 1a. The isotherms for all samples were classified as type I according to the International Union of Pure and Applied Chemistry (IUPAC) classification, being typical of microporous materials with pore width below $2 \mathrm{~nm} \mathrm{[38].}$

The pore size distribution curves for samples AC-1A, AC-2A, AC-1B, and AC$2 \mathrm{~B}$ are presented in Fig. $1 \mathrm{~b}-\mathrm{e}$, respectively. It can be seen that all the activated 

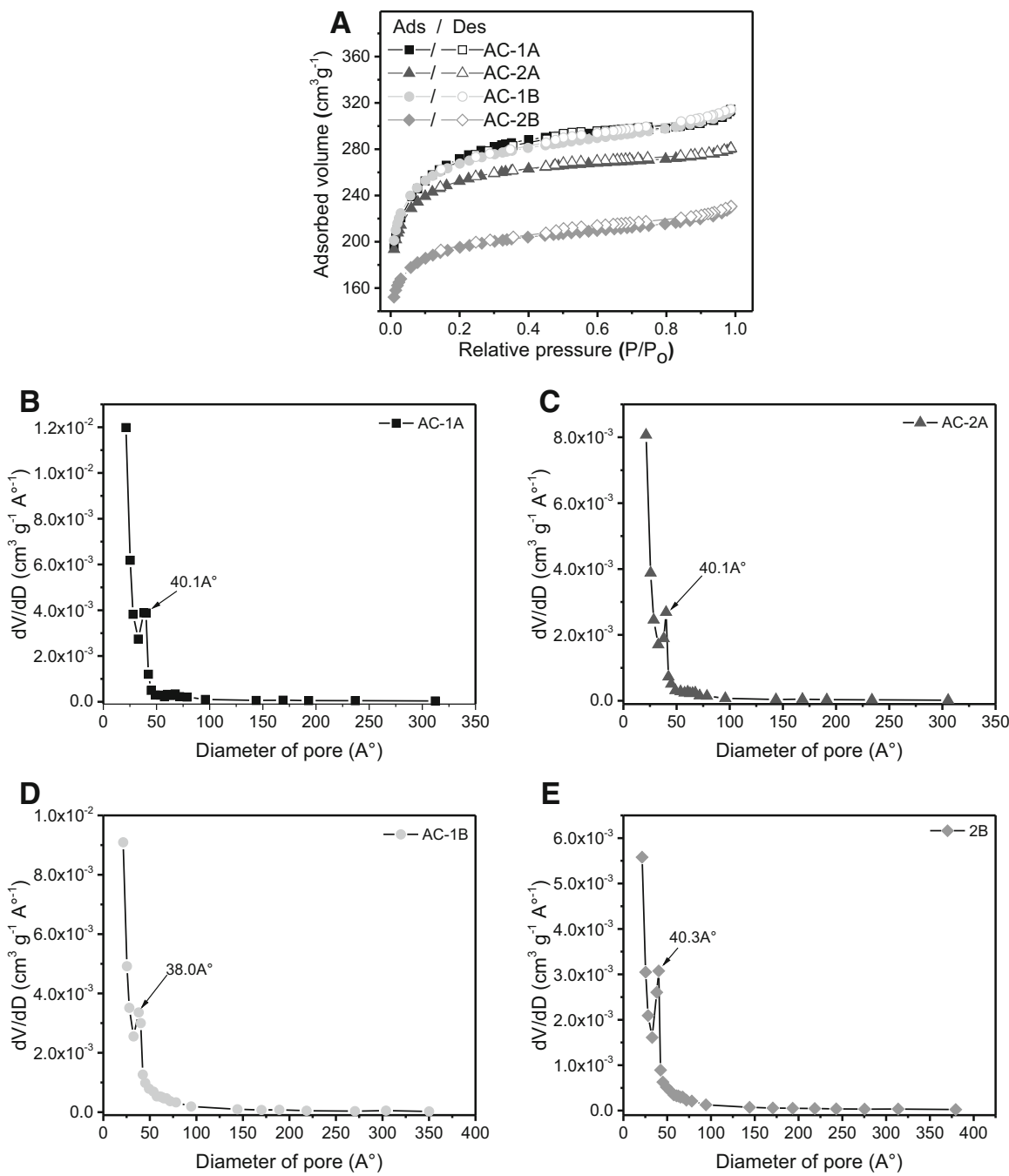

Fig. 1 a Nitrogen adsorption-desorption isotherms for activated carbon samples (filled symbols for adsorption branch, hollow symbols for desorption branch). Pore size distribution for b AC-1A, c AC-2A, d $\mathrm{AC}-1 \mathrm{~B}$, and e $\mathrm{AC}-2 \mathrm{~B}$

carbon materials presented a mixture of micropores and mesopores, with a peak maximum at around $40 \AA$ (4 $\mathrm{nm})$.

The effects of the different types of chemical agents and impregnation ratios on the BET surface area, micropore area, external surface area, total pore volume, micropore volume, mesopore volume, and yield are presented in Table 2.

As can be seen from the results in Fig. 1a and Table 2, the adsorbed $\mathrm{N}_{2}$ volume differed depending on the ratio of the activation agents used. The highest surface area was obtained for the AC-1A material (100 g sapelli wood sawdust $+20 \mathrm{~g}$ lime $\left.+80 \mathrm{~g} \mathrm{ZnCl}_{2}\right)$, followed by $\mathrm{AC}-1 \mathrm{~B}(100 \mathrm{~g}$ sapelli wood sawdust $+20 \mathrm{~g}$ 
Table 2 Textural properties of activated carbon materials

\begin{tabular}{llllllll}
\hline Sample & $\begin{array}{l}\text { BET } \\
\text { surface } \\
\text { area } \\
\left(\mathrm{m}^{2} \mathrm{~g}^{-1}\right)\end{array}$ & $\begin{array}{l}t \text {-Plot } \\
\text { micropore } \\
\text { area } \\
\left(\mathrm{m}^{2} \mathrm{~g}^{-1}\right)\end{array}$ & $\begin{array}{l}t \text {-Plot external } \\
\text { surface area } \\
\left(\mathrm{m}^{2} \mathrm{~g}^{-1}\right)\end{array}$ & $\begin{array}{l}\text { Total pore } \\
\text { volume } \\
\left(\mathrm{cm}^{3} \mathrm{~g}^{-1}\right)\end{array}$ & $\begin{array}{l}t \text {-Plot } \\
\text { micropore } \\
\text { volume } \\
\left(\mathrm{cm}^{3} \mathrm{~g}^{-1}\right)\end{array}$ & $\begin{array}{l}\text { Mesopore } \\
\text { volume } \\
\left(\mathrm{cm}^{3} \mathrm{~g}^{-1}\right)\end{array}$ & $\begin{array}{l}\text { Yield } \\
(\%)\end{array}$ \\
\hline AC-1A & 914.08 & 518.65 & 395.43 & 0.55385 & 0.27025 & 0.28360 & 25.15 \\
AC-1B & 874.72 & 560.60 & 314.11 & 0.52327 & 0.25177 & 0.27151 & 25.91 \\
AC-2A & 805.06 & 435.17 & 369.89 & 0.44205 & 0.20864 & 0.23342 & 24.26 \\
AC-2B & 647.05 & 405.89 & 241.15 & 0.34443 & 0.20020 & 0.14424 & 24.88 \\
\hline
\end{tabular}

lime $+40 \mathrm{~g} \mathrm{ZnCl}_{2}+40 \mathrm{~g} \mathrm{FeCl}_{3}$ ), then $\mathrm{AC}-2 \mathrm{~A}$ (150 g sapelli wood sawdust $+20 \mathrm{~g}$ lime $+80 \mathrm{~g} \mathrm{ZnCl}_{2}$ ), and lastly $\mathrm{AC}-2 \mathrm{~B}$ (150 g sapelli wood sawdust $+20 \mathrm{~g}$ lime $+40 \mathrm{~g} \mathrm{ZnCl}_{2}+40 \mathrm{~g} \mathrm{FeCl}_{3}$ ); see Table 2. The difference in total surface area between $\mathrm{AC}-1 \mathrm{~B}$ and $\mathrm{AC}-2 \mathrm{~A}$ was only $8.0 \%$ of the surface area of AC1B. From these results, it is possible to infer that the ratio between the total amount of inorganics in the biomass and the inorganic components is very important for the surface area of, as well as pore development in, the activated carbon materials [39]. The adsorbents with higher inorganic content (AC-1A and AC-1B) presented higher surface area and higher pore volume compared with the adsorbents with lower amounts of inorganics introduced during preparation of the activated carbon (AC$2 \mathrm{~A}$ and $\mathrm{AC}-2 \mathrm{~B})[40,41]$.

Another parameter that is useful for analysis of these activated carbon materials is the ratio $S_{\text {micropore }} / S_{\text {total }}$, expressed as a percentage. This ratio was 56.74, 64.09, 54.05 , and $62.73 \%$ for $\mathrm{AC}-1 \mathrm{~A}, \mathrm{AC}-1 \mathrm{~B}, \mathrm{AC}-2 \mathrm{~A}$, and $\mathrm{AC}-2 \mathrm{~B}$, respectively. The lime $+\mathrm{ZnCl}_{2}+\mathrm{FeCl}_{3}$ activating agent employed in the preparation of $\mathrm{AC}-1 \mathrm{~B}$ and $\mathrm{AC}-2 \mathrm{~B}$ resulted in a predominantly microporous adsorbent, whereas activating the carbon with lime $+\mathrm{ZnCl}_{2}$ resulted in a material with a slightly lower amount of microporous material. However, comparing all the results, one can infer that each of the four activated carbon materials presented a mixture of micro- and mesopores.

Furthermore, analyzing these results, it is expected that the sorption capacity of AC-1B would be very close to that of AC-2A, since these materials did not exhibit remarkable differences in surface area (difference of only $8.0 \%$ ). Also the inorganic components used to form the paste with the organic precursor $(20 \mathrm{~g}$ lime $+80 \mathrm{~g} \mathrm{ZnCl}_{2}$ or $20 \mathrm{~g}$ lime $+40 \mathrm{~g} \mathrm{ZnCl}_{2}+40 \mathrm{~g} \mathrm{FeCl}_{3}$ ) presented practically the same performance for combinations with 1.0:1.0 (inorganic:organic) ratio. Only AC-2B presented worst surface area, being $19.6 \%$ lower than for AC-2A, $26.0 \%$ lower than for $\mathrm{AC}-1 \mathrm{~B}$, and $29.2 \%$ lower than for $\mathrm{AC}-1 \mathrm{~A}$. Use of $\mathrm{ZnCl}_{2}$ as an activating agent is well known in literature [39-41], whereas use of $\mathrm{FeCl}_{3}$ as an activating agent for production of activated carbon is more recent in literature [27].

In addition, the ratio $V_{\text {micropore }} / V_{\text {total }}$ expressed as a percentage could be another useful parameter for analysis of these activated carbon materials. Its value was $48.79,48.11,47.20$, and $58.13 \%$ for $\mathrm{AC}-1 \mathrm{~A}, \mathrm{AC}-1 \mathrm{~B}, \mathrm{AC}-2 \mathrm{~A}$, and $\mathrm{AC}-2 \mathrm{~B}$, respectively. Analyzing these results, only AC-2B (150 g biomass $+20 \mathrm{~g}$ lime $+40 \mathrm{~g} \mathrm{ZnCl} 2+40 \mathrm{~g} \mathrm{FeCl}_{3}$ ) presented a predominance of micropores, 
because this ratio was slightly higher than $50 \%$. On the other hand, AC-1A, AC$1 \mathrm{~B}$, and $\mathrm{AC}-2 \mathrm{~A}$ presented $V_{\text {micropore }} / V_{\text {total }}$ ratios lower than $50 \%$, indicating that these materials were predominantly mesoporous. Although this analysis differs from the analysis of the ratio $S_{\text {micropore }} / S_{\text {total }}$, for which all the activated carbon materials presented a value higher than $50 \%$, both analyses indicate that all the activated carbon materials possess micropores and mesopores in their structure, and these pores are responsible for the sorption capacity of the obtained adsorbents [42-45].

In preparation of activated carbon, yield is an important parameter, usually being defined as the final weight of activated carbon produced after activation, washing, and drying, divided by the initial weight of raw material, both on dry basis [27, 46]. Table 2 also presents the yield for carbon preparation achieved in this work. It is observed from Table 2 that the type and composition of activating agent was not relevant for the yield. The global yield of activated carbon varied in the range from 24.26 to $25.91 \%$, considering the initial mass of sawdust used.

Different results were obtained in other studies; For instance, Saucier et al. [27] used cocoa shells as precursor and achieved yield of $20 \%$, whereas Gomez-Serrano et al. [46] achieved 37.2-42.3\% for production of activated carbon from chestnut wood. Such differences in the yield of activated carbon can be attributed to the different pyrolysis conditions and precursor types used.

Fourier-transform infrared (FTIR) analysis was carried out to identify the functional groups on the surface of the AC materials. Such analysis enables better understanding of surface features that could promote improved uptake of $o$-cresol. The FTIR spectra for samples AC-1A, AC-1B, AC-2A, and AC-2B are presented in Supplementary Fig. 2, and their band assignments in Table 3 [27, 28, 47]. The activated carbon materials presented many functional groups on the surface, including $\mathrm{O}-\mathrm{H}$ group of phenol, carboxylic acid, alcohol, aromatic rings, carboxylates, ether, and ester groups [27, 28, 47]. It seems that the main groups on the surface of the activated carbon materials were slightly hydrophilic, including oxygenated groups (carboxylates, phenol, esters, ethers, alcohols, etc.); this is in agreement with the $n$-heptane/water analysis, which provided additional evidence for the hydrophilic surface of the carbon materials (see Supplementary Fig. 2), as discussed below.

The functional groups present on the AC materials were also confirmed using a modified potentiometric Boehm titration method [31]. The total acidity was composed of carboxylic acid, phenols, and lactone groups. In this work, the fractions of these functional groups with $\mathrm{NaCO}_{3}$ and $\mathrm{NaHCO}_{3}$ were not determined, because it is very difficult to eliminate $\mathrm{CO}_{2}$ from the aqueous solution, as observed in our laboratory by potentiometric titrations and as also discussed in literature [31]. The total acidity of samples AC-1A, AC-2A, AC-1B, and AC-2B was 0.559, 0.594, 0.601 , and $0.606 \mathrm{mmol} \mathrm{g}^{-1}$, respectively. The total basicity of all the activated carbon materials was $0.000 \mathrm{mmol} \mathrm{g}^{-1}$, with the exception of $\mathrm{AC}-1 \mathrm{~B}$, for which it was $0.009 \mathrm{mmol} \mathrm{g}{ }^{-1}$. Based on these results, it is seen that lime $+\mathrm{ZnCl}_{2}+\mathrm{FeCl}_{3}$ promoted a slightly higher amount of acidic groups on the activated carbon adsorbent compared with lime $+\mathrm{ZnCl}_{2}$. It should be noted that such an increase of the functional groups on the surface of the activated carbon does not mean an increase in the sorption capacity, since the sorption depends on the interaction of the 
Table 3 FTIR vibrational bands of AC-1A, AC-2A, AC-1B, and AC-2B

\begin{tabular}{|c|c|}
\hline \multicolumn{2}{|c|}{ FTIR band $\left(\mathrm{cm}^{-1}\right)$} \\
\hline AC-1A & Assignment \\
\hline 3411 & $\mathrm{O}-\mathrm{H}$ stretching \\
\hline 2921 & $\mathrm{C}-\mathrm{H}$ asymmetric stretching \\
\hline 2853 & $\mathrm{C}-\mathrm{H}$ symmetric stretching \\
\hline 1610 & Aromatic ring mode \\
\hline 1563 & Asymmetric carboxylate stretching and aromatic ring mode \\
\hline 1452 & Symmetric carboxylate stretching and aromatic ring mode \\
\hline 1421 & Aromatic ring mode \\
\hline 1099 & Asymmetric $\mathrm{C}-\mathrm{O}-\mathrm{C}$ ether and $\mathrm{O}-\mathrm{C}-\mathrm{C}$ of aromatic ester, $\mathrm{C}-\mathrm{O}$ phenol \\
\hline 803 & $\mathrm{CH}$ out-of-plane bends of aromatic rings \\
\hline \multicolumn{2}{|l|}{ AC-2A } \\
\hline 3404 & $\mathrm{O}-\mathrm{H}$ stretching \\
\hline 2920 & $\mathrm{C}-\mathrm{H}$ asymmetric stretching \\
\hline 2852 & $\mathrm{C}-\mathrm{H}$ symmetric stretching \\
\hline 1572 & Asymmetric carboxylate stretching and aromatic ring mode \\
\hline 1383 & $\mathrm{C}-\mathrm{H}$ bending \\
\hline 1136 & Asymmetric $\mathrm{C}-\mathrm{O}-\mathrm{C}$ ether and $\mathrm{O}-\mathrm{C}-\mathrm{C}$ of aromatic ester, $\mathrm{C}-\mathrm{O}$ phenol \\
\hline 885,811 & $\mathrm{CH}$ out-of-plane bends of aromatic rings \\
\hline \multicolumn{2}{|l|}{$\mathrm{AC}-1 \mathrm{~B}$} \\
\hline 3384 & $\mathrm{O}-\mathrm{H}$ stretching \\
\hline 2923 & $\mathrm{C}-\mathrm{H}$ asymmetric stretching \\
\hline 2852 & $\mathrm{C}-\mathrm{H}$ symmetric stretching \\
\hline 1583 & Asymmetric carboxylate stretching and aromatic ring mode \\
\hline 1379 & $\mathrm{C}-\mathrm{H}$ bending \\
\hline 1167 & Asymmetric $\mathrm{C}-\mathrm{O}-\mathrm{C}$ ether and $\mathrm{O}-\mathrm{C}-\mathrm{C}$ of aromatic ester, $\mathrm{C}-\mathrm{O}$ phenol \\
\hline $885,812,752$ & $\mathrm{CH}$ out-of-plane bends of aromatic rings \\
\hline \multicolumn{2}{|l|}{$\mathrm{AC}-2 \mathrm{~B}$} \\
\hline 3417 & O-H stretching \\
\hline 2918 & $\mathrm{C}-\mathrm{H}$ asymmetric stretching \\
\hline 2853 & $\mathrm{C}-\mathrm{H}$ symmetric stretching \\
\hline 1617,1565 & Asymmetric carboxylate stretching and aromatic ring mode \\
\hline 1460 & Aromatic ring mode \\
\hline 1383 & $\mathrm{C}-\mathrm{H}$ bending \\
\hline 1104 & Asymmetric $\mathrm{C}-\mathrm{O}-\mathrm{C}$ ether and $\mathrm{O}-\mathrm{C}-\mathrm{C}$ of aromatic ester, $\mathrm{C}-\mathrm{O}$ phenol \\
\hline 803 & $\mathrm{CH}$ out-of-plane bends of aromatic rings \\
\hline
\end{tabular}

Assignments based on literature [25, 26, 40]

adsorbate with the adsorbent, while textural characteristics of the adsorbent such as the surface area and total pore volume also play a decisive role in the overall adsorption. 
Surface features of the materials could influence the interaction between adsorbent and adsorbate in the adsorption process. The adsorption ratio of vapors of solvents with different polarity (water $=$ hydrophilic, $n$-heptane $=$ hydrophobic) [48-50] was used to characterize the surface of the AC materials; the results are shown in Fig. 2. As seen from this figure, the adsorption ratios between water and $n$ heptane were below 1, implying that the $\mathrm{AC}$ materials have a more hydrophilic surface. Comparing the activating agents, samples $\mathrm{AC}-1 \mathrm{~B}$ and $\mathrm{AC}-2 \mathrm{~B}$ with $\mathrm{FeCl}_{3}$ (20 g lime $+40 \mathrm{~g} \mathrm{ZnCl}_{2}+40 \mathrm{~g} \mathrm{FeCl}_{3}$ ) were less hydrophilic compared with the samples prepared using $\mathrm{ZnCl}_{2}\left(20 \mathrm{~g}\right.$ lime $\left.+80 \mathrm{~g} \mathrm{ZnCl}_{2}\right)$, i.e., AC-1A and AC-2A (Fig. 2). For hydrophobic materials, the $n$-heptane/water ratio reaches values of 10 or more, e.g., for hydrophobic polysiloxanes [48]. However, composite materials containing silicate structure mixed with carbonized materials present $n$-heptane/ water adsorption ratios ranging from 2 to 4 [48]. Based on the adsorption results for the solvent vapors and the FTIR data, it can be concluded that the process of producing activated carbon using microwaves generated an oxygen-rich surface with hydrophilic characteristics.

The results shown in Supplementary Fig. 2 (FTIR analysis) and Fig. 2 (water/nheptane adsorption) suggest that varying the composition or type of chemical activating agent did not have remarkable effects on the surface of the four activated carbon materials, being insufficient to explain the difference in their sorption capacities. Therefore, textural properties such as the specific surface area, total pore volume, and micropore and mesopore volumes will be the main characteristics causing the different sorption capacities of the activated carbon materials.

In the field of environmental science, $\mathrm{pH}_{\mathrm{pzc}}$ determines how easily a substrate can adsorb potentially harmful charged components $[30,51]$. When the $\mathrm{pH}$ of the solution exceeds $\mathrm{pH}_{\mathrm{pzc}}$, the adsorbent surface is negative and can adsorb positively charged species, whereas when $\mathrm{pH}<\mathrm{pH}_{\mathrm{pzc}}$, the adsorbent surface presents positive charge, being suitable for adsorption of negatively charged species [30].

Figure 3 shows that the $\mathrm{pH}_{\mathrm{pzc}}$ value for $\mathrm{AC}-1 \mathrm{~A}$ and $\mathrm{AC}-2 \mathrm{~A}$ (activated $20 \mathrm{~g}$ lime $+80 \mathrm{~g} \mathrm{ZnCl}_{2}$ ) was 4.96 and 5.28, respectively. However, for samples AC-1B

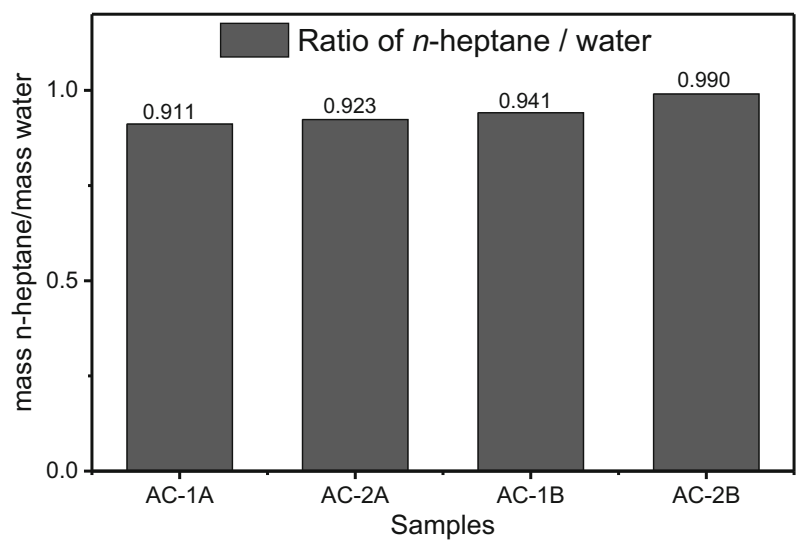

Fig. 2 Solvent vapor adsorption analysis 


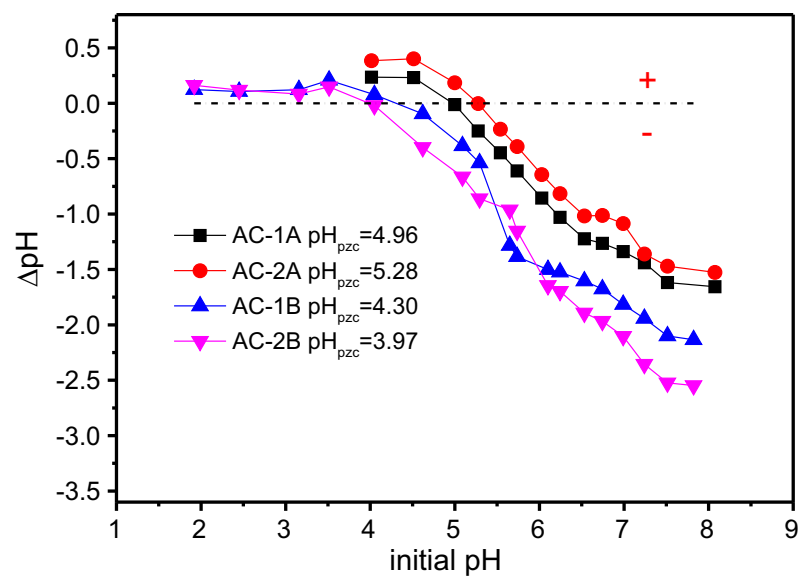

Fig. 3 Point of zero charge curves for AC samples

and $\mathrm{AC}-2 \mathrm{~B}$ (activated with $20 \mathrm{~g}$ lime $+40 \mathrm{~g} \mathrm{ZnCl}_{2}+40 \mathrm{~g} \mathrm{FeCl}$ ), the $\mathrm{pH}_{\mathrm{pzc}}$ values were slightly different: 4.30 and 3.97 , respectively. This means that the activated carbon materials obtained using $\mathrm{FeCl}_{3}$ (AC-1B and $\mathrm{AC}-2 \mathrm{~B}$ ) as activating agent had surfaces with more acidic behavior compared with those prepared using $\mathrm{ZnCl}_{2}$ (AC-1A and AC-2A). This behavior is in agreement with the total acidity of the activated carbon materials as described above, where the activated carbon materials obtained using $\mathrm{FeCl}_{3}(20 \mathrm{~g}$ lime $+40 \mathrm{~g} \mathrm{ZnCl} 2+40 \mathrm{~g} \mathrm{FeCl}$ ) presented more total acidic groups than those obtained using only $\mathrm{ZnCl}_{2}(20 \mathrm{~g}$ lime $+80 \mathrm{~g}$ $\mathrm{ZnCl}_{2}$ ) as activating agent.

Experiments using $o$-cresol solutions with initial $\mathrm{pH}$ in the range of 4.0-10.0 revealed that the initial $\mathrm{pH}$ of the adsorbate solution had no significant effect when its value was varied from 4.0 to 9.0. However, at $\mathrm{pH} 10$, the percentage removal of $o$-cresol was decreased by at least $25 \%$. Considering that the $\mathrm{pH}$ of treated effluents should be close to neutrality for release into the environment, the initial $\mathrm{pH}$ of the $o$ cresol solution was fixed at 7.0 for all subsequent experiments.

\section{Adsorption kinetics}

Adsorption kinetics is known to be important in many heterogeneous systems and time-dependent processes. Kinetic analysis allows for determination of the rate of adsorption, which determines the time of contact between the adsorbent and adsorbate required for the system to reach equilibrium. Therefore, for evaluation and regeneration of an adsorbent, it is important to understand the rate of the adsorption process [18, 27, 36, 52].

To investigate the adsorption kinetics of $o$-cresol on the four AC materials, pseudo-first-order, pseudo-second-order, and fractional-order kinetic models were used. The fitting parameters for the kinetic models for all the AC samples for two initial concentrations of $o$-cresol are presented in Table 4. To verify the suitability of the models, the standard deviation of residues (SD) was taken into account, with a 


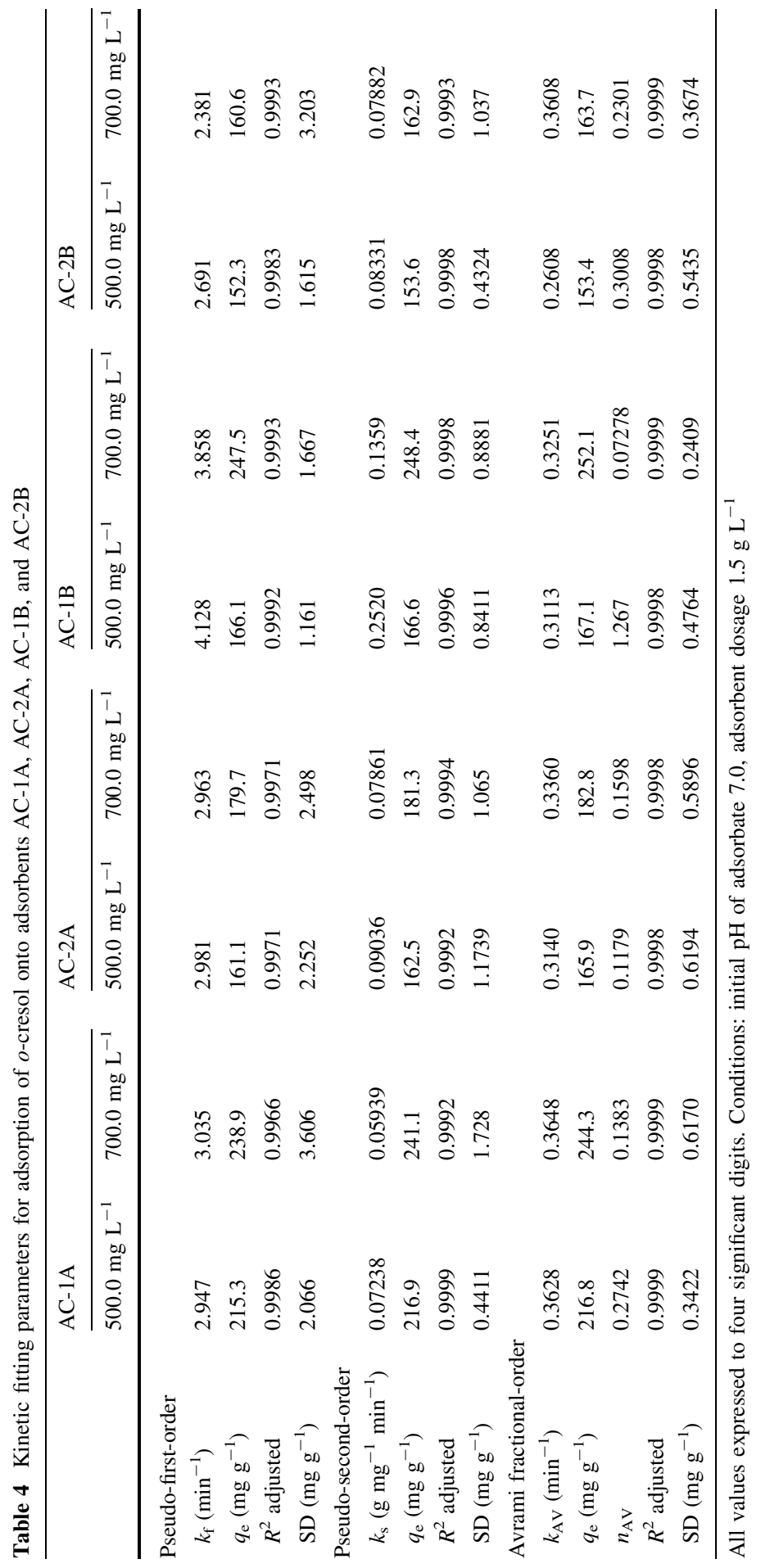


lower value indicating less difference between theoretical and experimental $q_{t}$ values [27, 51].

The fractional-order model presented the lowest SD values (varying from 0.2409 to 0.6194) for all adsorbents and initial concentrations, meaning that the $q_{t}$ values predicted by the fractional-order model were closer to those measured experimentally. The pseudo-first-order model presented SD values varying from 1.161 to 3.606, while the SD values for the pseudo-second-order model varied from 0.4324 to 1.728 .

Such a fractional-order model indicates that the adsorption process is complex or has multiple pathways, with the possibility that the adsorption mechanism changes during the adsorption process [37, 51]. Instead of the adsorption mechanism exhibiting only an integer kinetic order, it could follow multiple kinetic orders that change during contact of the $o$-cresol with the adsorbent [37]. The $n_{\mathrm{AV}}$ exponent indicates the multiple kinetic order of the adsorption process, usually being a fractional value.

To ensure that adsorption equilibrium was reached, in subsequent experiments, the contact time between the AC materials and $o$-cresol was kept at $120 \mathrm{~min}$.

\section{Adsorption equilibrium}

The isotherm provides information about the relationship between the $o$-cresol adsorbed on the solid phase and its concentration in the liquid phase when the adsorption process reaches equilibrium $[53,54]$. The fit curves (at $45^{\circ} \mathrm{C}$ ) and the parameters of the Langmuir, Freundlich, and Sips isotherm models are presented in Fig. 4 and Table 5, respectively.

The experimental procedure to obtain the isotherm data was carried out at various temperatures between 25 and $45{ }^{\circ} \mathrm{C}$ with contact time of $120 \mathrm{~min}$, initial pH of $o$ cresol solution of 7.0, and adsorbent dosage of $1.5 \mathrm{~g} \mathrm{~L}^{-1}$. All isotherms presented similar trends for all samples and temperature ranges. Table 5 presents the fitting parameters and adsorption isotherms for $o$-cresol onto AC-1A, AC-1B, AC-2A, and $\mathrm{AC}-2 \mathrm{~B}$ at various temperatures. Based on the SD values, the Sips model was the most suitable to describe the equilibrium data for adsorption of $o$-cresol onto the four AC materials (AC-1A, AC-1B, AC-2A, and AC-2B) at all temperatures (25, 35 , and $45{ }^{\circ} \mathrm{C}$ ) (Table 5). The Sips model showed the lowest SD values, meaning that its theoretical $q_{\mathrm{e}}$ values were closer to those found experimentally (Table 5). Strengthening the argument for the suitability of the Sips model, as for the SD values, the $R_{\text {adj }}^{2}$ values also confirm that the Sips isotherm is best for modeling the adsorption of $o$-cresol onto our AC materials.

The effect of temperature on the percentage removal of $o$-cresol by the AC materials was also evaluated in this work; the results are presented in Table 5. For all the AC materials, it seems that temperature did not have a remarkable effect on the $Q_{\max }$ value, albeit increasing from 221.4 to $239.4 \mathrm{mg} \mathrm{g}^{-1}$ for sample AC-1A, from 220.5 to $234.6 \mathrm{mg} \mathrm{g}^{-1}$ for sample AC-2A, from 219.5 to $234.9 \mathrm{mg} \mathrm{g}^{-1}$ for sample AC-1B, and from 183.4 to $198.8 \mathrm{mg} \mathrm{g}^{-1}$ for sample AC-2B. 

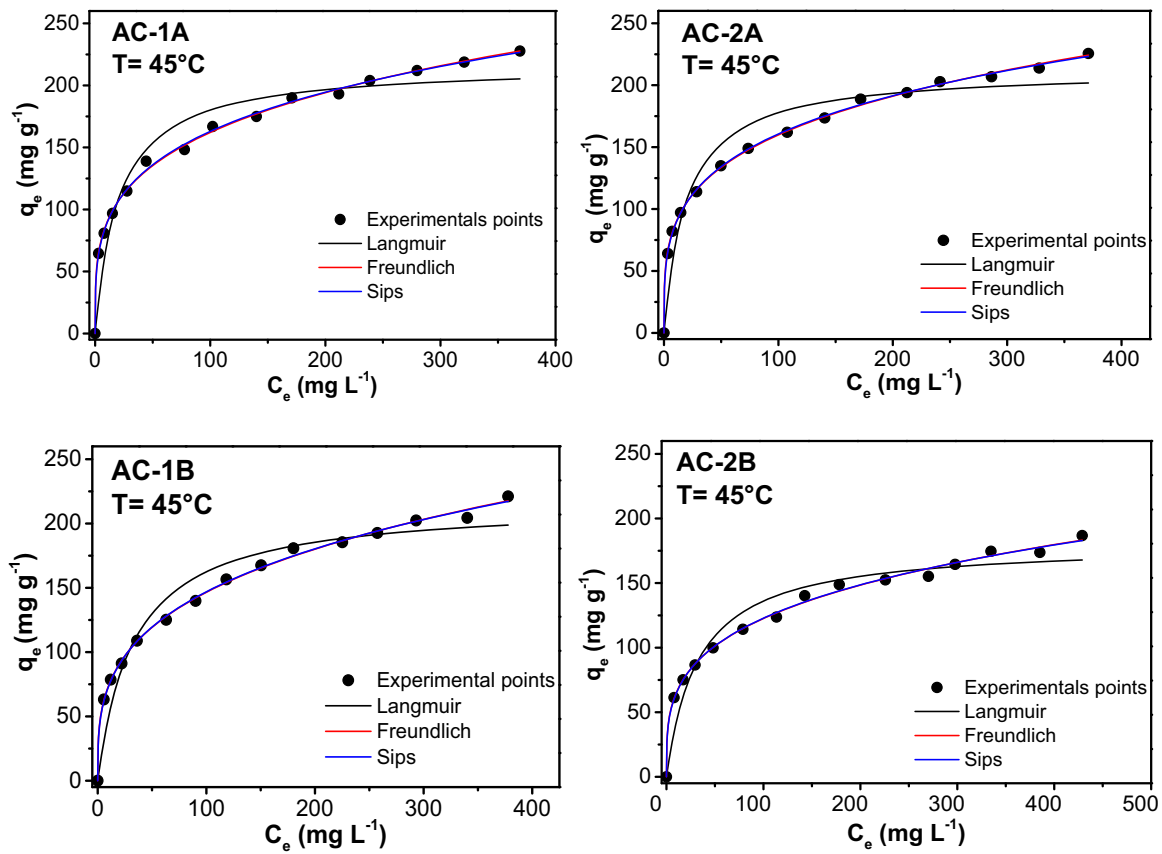

Fig. 4 Adsorption isotherms of $o$-cresol on activated carbon materials at $45^{\circ} \mathrm{C}$

Plots of $Q_{\max }$ as obtained from the Sips isotherm model at $45{ }^{\circ} \mathrm{C}$ versus $S_{\mathrm{BET}}$ and total pore volume are shown in Fig. 5a and b, respectively. It is observed that higher $S_{\mathrm{BET}}$ and $V_{\text {total }}$ values correspond to activated carbon materials with higher sorption capacity. In practice, samples $\mathrm{AC}-2 \mathrm{~A}$ and $\mathrm{AC}-1 \mathrm{~B}$ had very similar $Q_{\max }$ values (234.6 and $234.9 \mathrm{mg} \mathrm{g}^{-1}$, respectively), while the difference in their surface area was $8.0 \%$ (805.06 versus $874.72 \mathrm{~m}^{2} \mathrm{~g}^{-1}$ ). The adsorbent material AC-1A presented the highest $Q_{\max }$, compatible with its higher $S_{\mathrm{BET}}$ value of $914.08 \mathrm{~m}^{2} \mathrm{~g}^{-1}$. The value of $Q_{\max }$ for $\mathrm{AC}-1 \mathrm{~A}$ was only $1.8 \%$ higher than for $\mathrm{AC}-1 \mathrm{~B}$, since the $S_{\mathrm{BET}}$ value was only $4.5 \%$ higher for $\mathrm{AC}-1 \mathrm{~A}$ than $\mathrm{AC}-1 \mathrm{~B}$. From these plots, it is also possible to conclude that the activated carbon materials with inorganic:sapelli sawdust ratio of 1:1 presented higher surface area and consequently higher $Q_{\max }$. In addition, $\mathrm{FeCl}_{3}$ is not a bad activating agent when mixed with $\mathrm{ZnCl}_{2}$. Analysis of total pore volume is provided in Fig. 5b. As in the earlier analysis, higher pore volume of the adsorbent led to higher sorption capacity. Based on this analysis, the order of the samples in terms of decreasing $Q_{\max }$ versus $V_{\text {total }}$ was as follows: AC$1 \mathrm{~A}>\mathrm{AC}-1 \mathrm{~B} \approx \mathrm{AC}-2 \mathrm{~A}>\mathrm{AC}-2 \mathrm{~B}$. In general, the sorption capacity of an adsorbate (e.g. $o$-cresol) from aqueous solution by AC depends, in addition to $S_{\mathrm{BET}}$, on various other factors including pore size, pore volume, micropore and mesopore volumes, etc. In this work, it was found that $S_{\mathrm{BET}}$ was not the only parameter influencing the $o$-cresol adsorption: basically, samples with higher total pore (micropore and mesopore) volume had higher $o$-cresol adsorption capacity (Fig. 5a, b). Sample AC-1A presented the highest total pore volume, both micropore and 


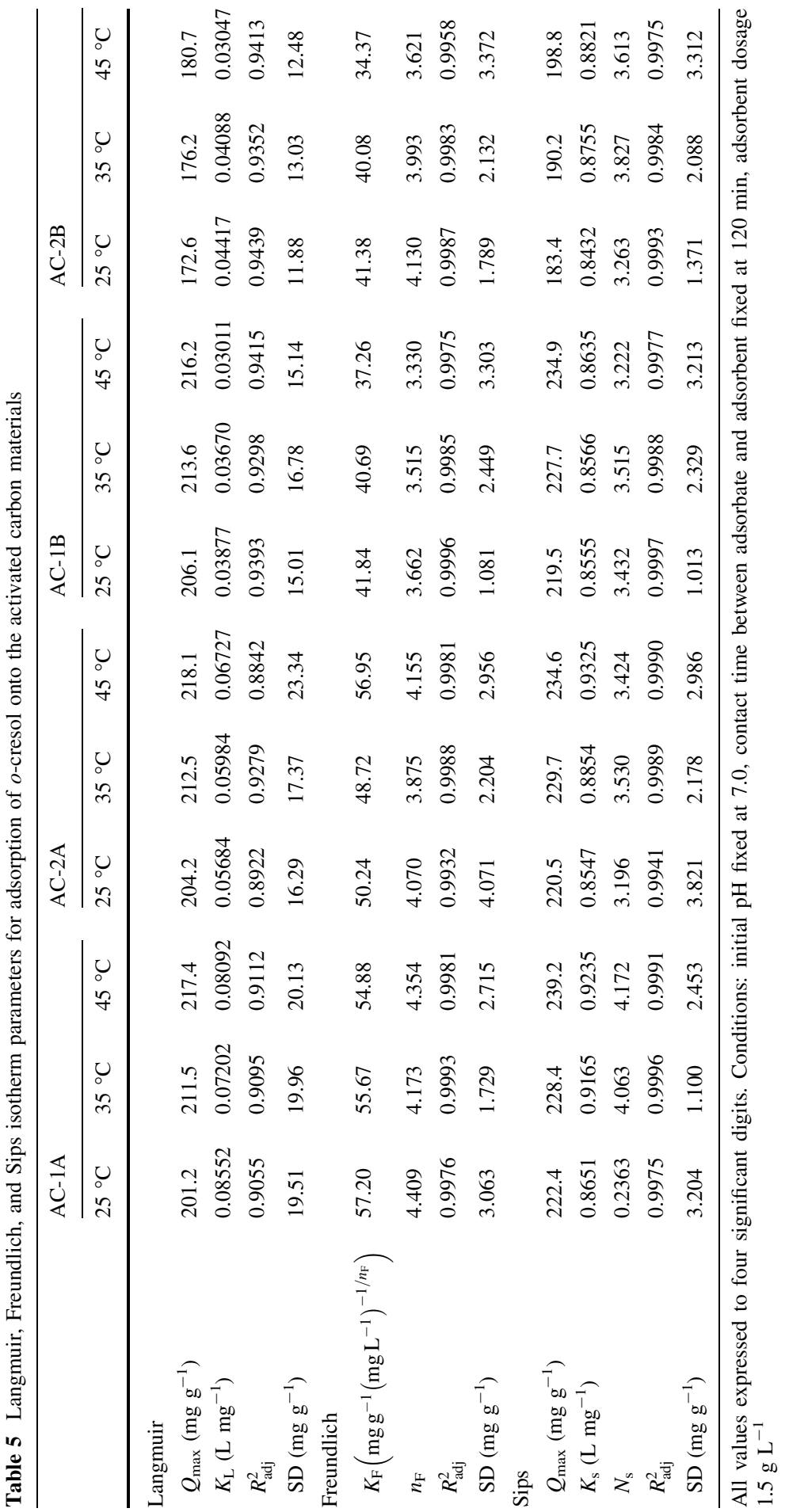


Fig. 5 Relations between $Q_{\max }$ of Liu isotherm at $45^{\circ} \mathrm{C}$ and a surface area and $\mathbf{b}$ total pore volume
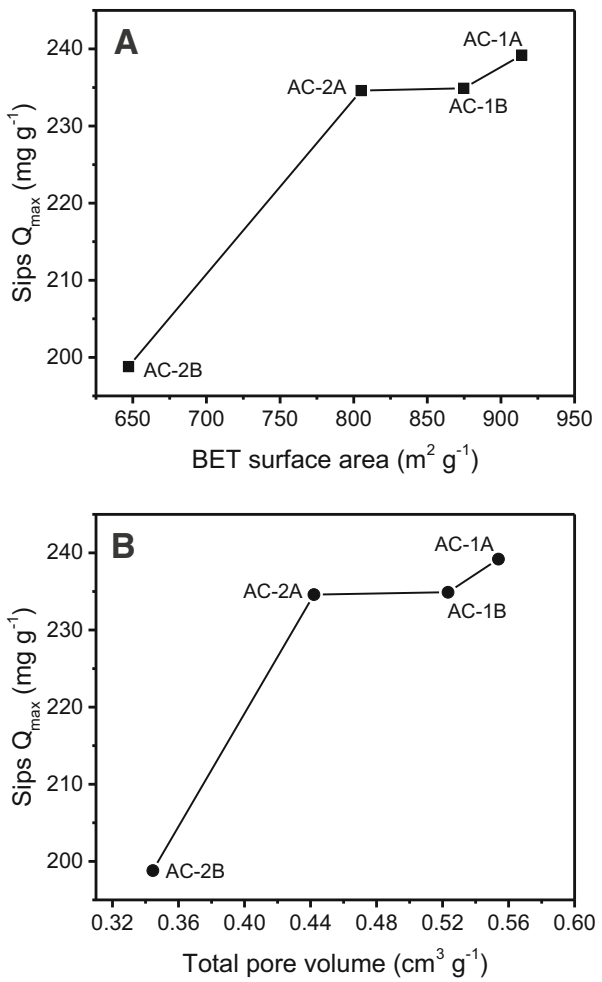

mesopore, as well as the highest $o$-cresol adsorption capacity, followed by samples AC-1B, AC-2A, and AC-2B, respectively.

\section{Comparison of adsorption capacity of different adsorbents}

Various adsorbents have been identified for adsorption of $o$-cresol as well as $m$ cresol and $p$-cresol; therefore, it is important to verify the performance of the adsorbents used in this work versus other adsorbents reported in literature. The $Q_{\max }$ value of $o$-cresol onto AC and other adsorbents is listed in Table 6 [55-60]. The $Q_{\max }$ values reported in Table 6 were obtained using the best experimental conditions of each study. As shown in this table, samples AC-1A, AC-2A, AC-1B, and AC-2B presented higher $Q_{\max }$ values compared with all other adsorbents presented in Table 6 [55-60]. This result is very important from the scientific point of view, because the adsorbents proposed in this work present the best performance when compared with the other adsorbents highlighted in Table 6, giving an indication that these adsorbents are very efficient.

\section{Desorption studies}

Adsorbent regeneration can be important to reduce the cost of the adsorption process in practical wastewater treatment systems $[52,58,59]$. Regeneration of the 
Table 6 Maximum sorption capacity of different adsorbents used for removal of various phenolic compounds

\begin{tabular}{|c|c|c|c|}
\hline Adsorbent & Phenolic adsorbate & $Q_{\max }\left(\mathrm{mg} \mathrm{g}^{-1}\right)$ & Reference \\
\hline Activated carbon from water hyacinth & $o$-Cresol & 123.6 & {$[55]$} \\
\hline Activated carbon from water hyacinth & $m$-Cresol & 123.1 & {$[55]$} \\
\hline Polymer-supported iron nanoparticles & $o$-Cresol & 1.02 & {$[56]$} \\
\hline Activated carbon from coconut shell & $p$-Cresol & 30.23 & [56] \\
\hline Commercial activated carbon & Cresol & 4.74 & [57] \\
\hline Fly ash & Cresol & 6.7 & {$[58]$} \\
\hline Clay and membrane & $o$-Cresol & 8.8 & [58] \\
\hline Montmorillonite & $o$-Cresol & 10.1 & {$[58]$} \\
\hline Carbon composites & $p$-Cresol & 86 & [59] \\
\hline Parthenium-based activated carbon & $p$-Cresol & 62.91 & {$[60]$} \\
\hline AC-1A microwave-activated carbon & $o$-Cresol & 239.2 & This work \\
\hline AC-1B microwave-activated carbon & $o$-Cresol & 234.6 & This work \\
\hline AC-2A microwave-activated carbon & $o$-Cresol & 234.9 & This work \\
\hline AC-2B microwave-activated carbon & $o$-Cresol & 198.8 & This work \\
\hline
\end{tabular}

activated carbon materials was examined through desorption experiments. Therefore, desorption experiments were carried out to regenerate all the adsorbents. $\mathrm{NaOH}(1.0-5.0 \mathrm{M})$ and $10 \% \mathrm{EtOH}+\mathrm{NaOH} \mathrm{M}$ and $50 \% \mathrm{EtOH}+\mathrm{NaOH} \mathrm{M}$ were used as eluents in the $o$-cresol desorption process (Fig. 6).

Pure $\mathrm{NaOH}$ solutions, up to $5 \mathrm{M}$, presented good recovery of adsorbents (between 74.84 and $81.56 \%)$. However, the mixture of EtOH (10 and $50 \%)+\mathrm{NaOH}(5 \mathrm{M})$ presented excellent desorption efficiency, desorbing more than $99.9 \%$ of $o$-cresol from all the activated carbon materials. These results show that addition of EtOH caused obvious enhancement of the amount of $o$-cresol desorbed.

Fig. 6 Desorption of $o$-cresol from samples AC-1A and AC$2 \mathrm{~A}$

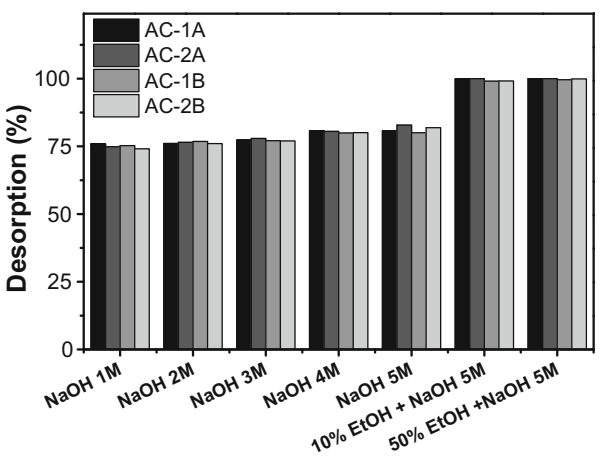




\section{Proposed adsorption mechanism}

Based on the characterization analysis, $\mathrm{pH}$ studies, kinetic and adsorption processes, and desorption experiments, the adsorption mechanism of $o$-cresol onto the activated carbon materials can be summarized as shown in Fig. 7. The adsorption mechanism involved in the adsorption process between the carbon surface and $o$ cresol might be governed by physical interactions such as $\pi-\pi$ interactions, hydrophobic interactions, and/or electron donor-acceptor complexation [57-60]. The electron donor-acceptor mechanism relies on aromatic rings of the $o$-cresol to act as electron acceptors while basic zones on the AC surface serve as electron donors [57]. The $\pi-\pi$ interactions are physical interactions between $\pi$ electrons of aromatic rings of the $o$-cresol and with $\pi$ electrons of the rings of AC [57-60], as shown in Fig. 8. Moreover, there is also a strong possibility that $o$-cresol sorption occurs through formation of hydrogen bonding with the $-\mathrm{OH}$ group present on the AC surface (Fig. 8) [57-60]. The AC materials present strong adsorption capacity for $o$-cresol, which could be related to formation of such hydrogen bonds [57-60] between $o$-cresol and oxygenated groups of the activated carbon. In the desorption experiments, the organic solvent EtOH helped to break up the interactions of $o$ cresol with the activated carbon surface, leading to desorption of $o$-cresol.

\section{Adsorption of simulated phenolic effluents}

Two simulated effluents containing several phenolic compounds, humic acid, and some salts with different compositions and concentrations were prepared (Table 1) to investigate the effectiveness and efficiency of treatment of simulated synthetic effluents using the activated carbon materials (Fig. 8).

The spectra of the synthetic phenolic effluents before and after treatment with the AC materials were recorded between 190 and $800 \mathrm{~nm}$ in the ultraviolet-visible (UV-Vis) region (Fig. 8). The areas under the absorption bands from 190 and $800 \mathrm{~nm}$ were used to measure the amount of phenolic compounds removed from the synthetic effluents. All of the activated carbon materials presented very good performance in treatment of the simulated effluents. The removal percentages for effluent A were 98.87, 97.42, 98.13, and 96.61\% for AC-1A, AC-1B, AC-1B, and AC-2B, respectively. For effluent B, which was slightly more concentrated than effluent A (Table 1), the removal of phenolic compounds was 96.81, 95.95, 96.31,

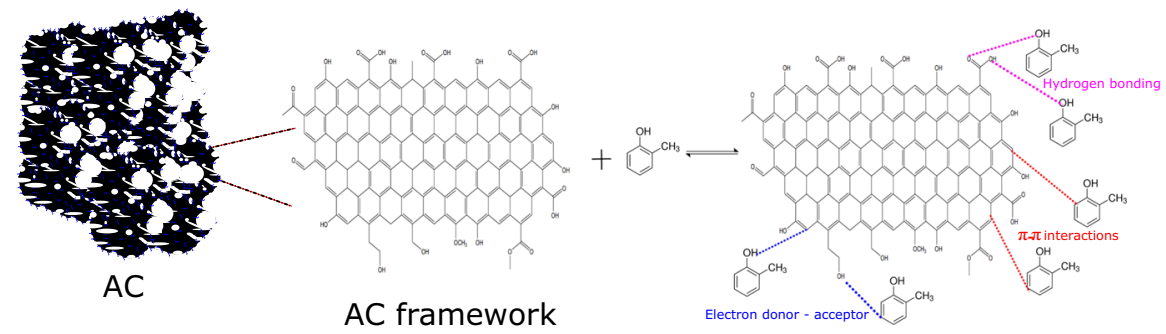

Fig. 7 Proposed adsorption mechanism between AC and $o$-cresol 
Fig. 8 UV-Vis spectra of simulated effluents A and B before and after treatment with all four AC materials; see Table 1 for effluent compositions
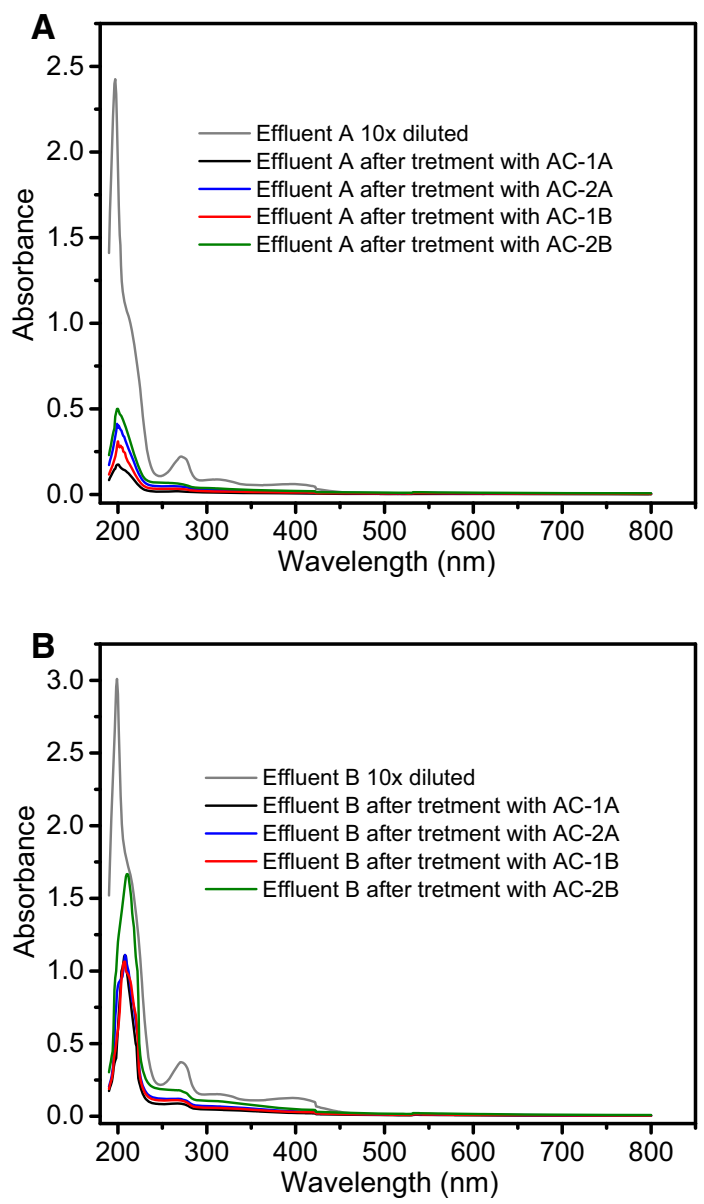

and $93.82 \%$ for $\mathrm{AC}-1 \mathrm{~A}, \mathrm{AC}-1 \mathrm{~B}, \mathrm{AC}-1 \mathrm{~B}$, and $\mathrm{AC}-2 \mathrm{~B}$, respectively. These results are in accordance with the porosity and adsorption data, which showed that the sorption capacity followed the order: AC-1A $>$ AC-1B $>$ AC-2A $>$ AC-2B, which is the same order as for $Q_{\max }$ versus $S_{\mathrm{BET}}$ in Fig. 4 .

Based on the removal efficiency for these synthetic effluents, it can be inferred that these AC materials might have very good applicability for removal of phenolic compounds from real industrial wastewater contaminated with phenols.

\section{Conclusions}

This study has proven that activated carbon materials with high $S_{\mathrm{BET}}$ values can be prepared from sapelli wood sawdust via a microwave heating process. The AC materials were microporous with $S_{\mathrm{BET}}$ values up to $914.08 \mathrm{~m}^{2} \mathrm{~g}^{-1}$. Variation of the 
ratios of the activation agent resulted in noticeable changes in the textural properties of the prepared activated carbon materials, as well as their surface chemistry.

Kinetic and equilibrium studies confirmed that the Avrami fractional-order model and Sips isotherm provided the best fit, indicating multilayer adsorption. The maximum amount of $o$-cresol adsorbed at $45{ }^{\circ} \mathrm{C}$ was 239.2, 234.6, 234.9, and $198.8 \mathrm{mg} \mathrm{g}^{-1}$ for $\mathrm{AC}-1 \mathrm{~A}, \mathrm{AC}-2 \mathrm{~A}, \mathrm{AC}-1 \mathrm{~B}$, and $\mathrm{AC}-2 \mathrm{~B}$, respectively. The AC materials showed excellent results in treatment of simulated industrial effluents, effectively removing at least $93.82 \%$ of mixtures containing high concentrations of phenols, organic matter, and saline concentrations. An adsorption mechanism is proposed, suggesting that donor-acceptor complexation, hydrogen bonding, and $\pi-$ $\pi$ interactions play key roles in the adsorption process.

Based on the presented data, it is possible to conclude that microwave heating enables production of efficient activated carbon with high surface area from sapelli wood sawdust.

Acknowledgments We would like to thank the National Council for Scientific and Technological Development (CNPq, Brazil) and The Academy of Sciences for Developing World (TWAS, Italy) for financial support and sponsorship. We also thank The Centre of Electron Microscopy (CME-UFRGS) for use of the SEM. We are once again grateful to Chemaxon for providing us with an academic research license for Marvin Sketch software version 16.6.6.0 (http://www.chemaxon.com) 2016, used for $o$-cresol physical-chemical properties.

\section{References}

1. R.G. Dolatto, I. Messerschmidt, B.F. Pereira, R. Martinazzo, G. Abate, Preconcentration of polar phenolic compounds from water samples and soil extract by liquid-phase microextraction and determination via liquid chromatography with ultraviolet detection. Talanta 148, 292-300 (2016)

2. H. Babich, D.L. Davis, Phenol: a review of environmental and health risks. Regul. Toxicol. Pharm. 1, 90-109 (1981)

3. C.A. Arenal, B.E. Sample, Wildlife toxicity assessment for phenol, in Wildlife toxicity assessments for chemicals of military concern, ed. by M.S. Johnson, M. Williams, G. Reddy, M. Quinn (Elsevier, Amsterdam, 2015), pp. 555-579

4. R. Wissiack, E. Rosenberg, Universal screening method for the determination of US Environmental Protection Agency phenols at the lower $n g 1^{-1}$ level in water samples by on-line solid-phase extraction-high-performance liquid chromatography-atmospheric pressure chemical ionization mass spectrometry within a single run. J. Chromatogr. A 963, 149-157 (2002)

5. H. Pasdar, R. Marand, Effect of phenol loading on wastewater treatment by activated sludge process. J. Basic Appl. Sci. Res. 3, 121-126 (2013)

6. C.E. Paisio, M.R. Quevedo, M.A. Talano, P.S. González, E. Agostini, Application of two bacterial strains for wastewater bioremediation and assessment of phenolics biodegradation. Environ. Technol. 35, 1802-1810 (2014)

7. T. Saitoh, K. Fukushima, A. Miwa, Combined use of surfactant-induced coagulation of poly(allylamine hydrochloride) with peroxidase-mediated degradation for the rapid removal of estrogens and phenolic compounds from water. Sep. Purif. Technol. 128, 11-17 (2014)

8. F. Bazzarelli, E. Piacentini, T. Poerio, R. Mazzei, A. Cassano, L. Giorno, Advances in membrane operations for water purification and biophenols recovery/valorization from OMWWs. J. Membr. Sci. 497, 402-409 (2016)

9. M. Irani, L.R. Rad, H. Pourahmad, I. Haririan, Optimization of the combined adsorption/photoFenton method for the simultaneous removal of phenol and paracetamol in a binary system. Micropor. Mesopor. Mater. 206, 1-7 (2015)

10. P.V. Aken, R.V. den Broeck, J. Degrève, R. Dewil, The effect of ozonation on the toxicity and biodegradability of 2,4-dichlorophenol-containing wastewater. Chem. Eng. J. 280, 728-736 (2015) 
11. A.M. Al-Hamdi, M. Sillanpaa, J. Dutta, Intermediate formation during photodegradation of phenol using lanthanum doped tin dioxide nanoparticles. Res. Chem. Intermed. 42, 3055-3069 (2016)

12. T.T.T. Dang, S.T.T. Le, D. Channei, W. Khanitchaidecha, A. Nakaruk, Photodegradation mechanisms of phenol in the photocatalytic process. Res. Chem. Intermed. (2016). doi:10.1007/s11164015-2417-3

13. N. Douara, B. Bestani, N. Benderdouche, L. Duclaux, Sawdust-based activated carbon ability in the removal of phenol-based organics from aqueous media. Desalin. Water Treat. 57, 5529-5545 (2016)

14. N. Singh, C. Balomajumder, Simultaneous biosorption and bioaccumulation of phenol and cyanide using coconut shell activated carbon immobilized Pseudomonas putida (MTCC 1194). J. Environ. Chem. Eng. 4, 1604-1614 (2016)

15. J. Pal, M.K. Deb, D.K. Deshmukh, Removal of phenol in aqueous solution by adsorption onto green synthesized coinage nanoparticles beads. Res. Chem. Intermed. 41, 8363-8379 (2015)

16. R. Sudha, K. Srinivasan, P. Premkumar, Kinetic, mechanism and equilibrium studies on removal of $\mathrm{Pb}$ (II) using Citrus limettioides peel and seed carbon. Res. Chem. Intermed. 42, 1677-1697 (2016)

17. G.S. dos Reis, M. Wilhelm, T.C.A. Silva, K. Rezwan, C.H. Sampaio, E.C. Lima, S.M.A.G.U. Souza, The use of design of experiments for the evaluation of the production of surface-rich activated carbon from sewage sludge via microwave and conventional pyrolysis. Appl. Therm. Eng. 93, 590-597 (2016)

18. G.S. dos Reis, M.A. Adebayo, E.C. Lima, C.H. Sampaio, L.D.T. Prola, Activated carbon from sewage sludge for preconcentration of copper. Anal. Lett. 49, 541-555 (2016)

19. P. Humpola, H. Odetti, J.C. Moreno-Pirajan, L. Giraldo, Activated carbons obtained from agroindustrial waste: textural analysis and adsorption environmental pollutants. Adsorption 22, 23-31 (2016)

20. B. Acevedo, R.P. Rocha, M.F.R. Pereira, J.L. Figueiredo, C. Barriocanal, Adsorption of dyes by ACs prepared from waste tyre reinforcing fibre: effect of texture, surface chemistry and $\mathrm{pH}$. J. Colloid Interf. Sci. 459, 189-198 (2015)

21. S. Malathi, N. Krishnaveni, R. Sudha, Adsorptive removal of lead(II) from an aqueous solution by chemically modified cotton seed cake. Res. Chem. Intermed. 42, 2285-2302 (2016)

22. M.J. Ahmed, Application of agricultural based activated carbons by microwave and conventional activations for basic dye adsorption: review. J. Environ. Chem. Eng. 4, 89-99 (2016)

23. Anonyme, Etude sur la traçabilité des bois exploités au Cameroun et des produits bois » exportés à partir du Cameroun [Study on the traceability of timber exploited in Cameroon and products "Wood" exported from Cameroon], Ministère des Forêts et de la Faune du Cameroun-Rapport de Tecsult Interna-tional Lte é, Yaounde (2007)

24. J.M. Sieliechi, P.S. Thue, Removal of paraquat from drinking water by activated carbon prepared from waste wood. Desalin. Water Treat. 55, 986-998 (2015)

25. R.H. Hesas, A. Arami-Niya, W.M.A.W. Daud, J.N. Sahu, Comparison of oil palm shell-based activated carbons produced by microwave and conventional heating methods using zinc chloride activation. J. Anal. Appl. Pyrolysis 104, 176-184 (2013)

26. X. Ge, X. Ma, Z. Wu, X. Xiao, Y. Yan, Modification of coal-based activated carbon with nitric acid using microwave radiation for adsorption of phenanthrene and naphthalene. Res. Chem. Intermed. 41, 7327-7347 (2015)

27. C. Saucier, M.A. Adebayo, E.C. Lima, R. Cataluna, P.S. Thuea, L.D.T. Prola, M.J. Puchana-Rosero, F.M. Machado, F.A. Pavan, G.L. Dotto, Microwave-assisted activated carbon from cocoa shell as adsorbent for removal of sodium diclofenac and nimesulide from aqueous effluents. J. Hazard. Mater. 289, 18-27 (2015)

28. C. Saucier, M.A. Adebayo, E.C. Lima, L.D.T. Prola, P.S. Thue, C.S. Umpierres, M.J. PuchanaRosero, F.M. Machado, Comparison of a homemade Bacury shell activated carbon with MWCNT for the removal of Brilliant Blue FCF food dye from aqueous solutions. Clean: Air, Soil, Water $\mathbf{4 3}$, 1389-1400 (2015)

29. J.C.P. Vaghetti, M. Zat, K.R.S. Bentes, L.S. Ferreira, E.V. Benvenutti, E.C. Lima, 4-Phenylenediaminepropylsilica xerogel as a sorbent for copper determination in waters by slurry-sampling ETAAS. J. Anal. At. Spectrom. 18, 376-380 (2003)

30. L.D.T. Prola, E. Acayanka, E.C. Lima, C.S. Umpierres, J.C.P. Vaghetti, W.O. Santos, S. Laminsi, P.T. Njifon, Comparison of Jatropha curcas shells in natural form and treated by non-thermal plasma as biosorbents for removal of reactive red 120 textile dye from aqueous solution. Ind. Crop. Prod. 46, 328-340 (2013) 
31. S.L. Goertzen, K. Theriault, A.M. Oickle, A.C. Tarasuk, H.A. Andreas, Standardization of the Boehm titration: Part $\mathrm{I}-\mathrm{CO}_{2}$ expulsion and endpoint determination. Carbon 48, 1252-1261 (2010)

32. E.C. Lima, R.V. Barbosa, J.L. Brasil, A.H.D.P. Santos, Evaluation of different permanent modifiers for the determination of arsenic, cadmium and lead in environmental samples by electrothermal atomic absorption spectrometry. J. Anal. At. Spectrom. 17, 1523-1529 (2002)

33. E.C. Lima, F. Barbosa Jr., F.J. Krug, U. Guaita, Tungsten-rhodium permanent chemical modifier for lead determination in digests of biological materials and sediments by electrothermal atomic absorption spectrometry. J. Anal. At. Spectrom. 14, 1601-1605 (1999)

34. E.C. Lima, F.J. Krug, J.A. Nóbrega, A.R.A. Nogueira, Determination of ytterbium in animal faeces by tungsten coil electrothermal atomic absorption spectrometry. Talanta 47, 613-623 (1998)

35. E.C. Lima, P.G. Fenga, J.R. Romero, W.F. de Giovani, Electrochemical behaviour of $\left[\mathrm{Ru}\left(4,4^{\prime}-\right.\right.$ $\mathrm{Me}_{2}$ bpy $\left.)_{2}\left(\mathrm{PPh}_{3}\right)\left(\mathrm{H}_{2} \mathrm{O}\right)\right]\left(\mathrm{ClO}_{4}\right)_{2}$ in homogeneous solution and incorporated into carbon paste electrodes: application to oxidation of benzylic compounds. Polyhedron 17, 313-318 (1998)

36. W.S. Alencar, E.C. Lima, B. Royer, B.D. dos Santos, T. Calvete, E.A. da Silva, C.N. Alves, Application of aqai stalks as biosorbents for the removal of the dye Procion Blue MX-R from aqueous solution. Sep. Sci. Technol. 47, 513-526 (2012)

37. E.C. Lima, M.A. Adebayo, F.M. Machado, Chapter 3-kinetic and equilibrium models of adsorption, in Carbon nanomaterials as adsorbents for environmental and biological applications, ed. by C.P. Bergmann, F.M. Machado (Springer, Berlin, 2015), pp. 33-69

38. K.S.W. Sing, D.H. Everett, R.A.W. Haul, L. Moscou, R.A. Pierotti, J. Rouquerol, T. Siemieniewska, Reporting physisorption data for gas/solid systems with special reference to the determination of surface area and porosity (recommendations 1984). Pure Appl. Chem. 57, 603-619 (1985)

39. O. Pezoti Jr., A.L. Cazetta, I.P.A.F. Souza, K.C. Bedin, A.C. Martins, T.L. Silva, V.C. Almeida, Adsorption studies of methylene blue onto $\mathrm{ZnCl}_{2}$-activated carbon produced from buriti shells (Mauritia flexuosa L.). J. Ind. Eng. Chem. 20, 4401-4407 (2014)

40. R.G. Pereira, C.M. Veloso, N.M. da Silva, L.F. de Sousa, R.C.F. Bonomo, A.O. de Souza, M.O.G. Souza, R.C.I. Fontan, Preparation of activated carbons from cocoa shells and siriguela seeds using $\mathrm{H}_{3} \mathrm{PO}_{4}$ and $\mathrm{ZnCl}_{2}$ as activating agents for BSA and $\alpha$-lactalbumin adsorption. Fuel Proc. Technol. 126, 476-486 (2014)

41. O. Pezoti Jr., A.L. Cazetta, R.C. Gomes, E.O. Barizão, I.P.A.F. Souza, A.C. Martins, T. Asefa, V.C. Almeida, Synthesis of $\mathrm{ZnCl}_{2}$-activated carbon from macadamia nut endocarp (Macadamia integrifolia) by microwave-assisted pyrolysis: optimization using RSM and methylene blue adsorption. J. Anal. Appl. Pyrol. 105, 166-176 (2014)

42. T.-H. Liou, Development of mesoporous structure and high adsorption capacity of biomass-based activated carbon by phosphoric acid and zinc chloride activation. Chem. Eng. J. 158, 129-142 (2010)

43. Z. Hu, M.P. Srinivasan, Mesoporous high surface area activated carbon. Micropor. Mesopor. Mater. 43, 267-275 (2001)

44. A.C. Lua, T. Yang, Characteristics of activated carbon prepared from pistachionut shell by zinc chloride activation under nitrogen and vacuum conditions. J. Colloid Interface Sci. 290, 505-513 (2005)

45. Z. Hu, M.P. Srinivasan, Y. Ni, Novel activation process for preparing highly microporous and mesoporous activated carbons. Carbon 39, 877-886 (2001)

46. V. Gomez-Serrano, E.M. Cuerda-Correa, M.C. Fernandez-Gonzales, M.F. Alexandre-Franco, A. Macias-Garcia, Preparation of activated carbons from chestnut wood by phosphoric acid-chemical activation: study of microporosity and fractal dimension. Mater. Lett. 59, 846-853 (2005)

47. T. Calvete, E.C. Lima, N.F. Cardoso, S.L.P. Dias, E.S. Ribeiro, Removal of brilliant green dye from aqueous solutions using home-made activated carbons. Clean: Air, Soil, Water 38, 521-532 (2010)

48. G.S. dos Reis, C.H. Sampaio, E.C. Lima, M. Wilhelm, Preparation of novel adsorbents based on combinations of polysiloxanes and sewage sludge to remove pharmaceuticals from aqueous solutions. Colloids Surf. A 497, 304-315 (2016)

49. M. Wilhelm, C. Soltmann, D. Koch, G. Grathwohl, Ceramers: functional materials for adsorption techniques. J. Eur. Ceram. Soc. 25, 271-276 (2005)

50. T. Prenzel, M. Wilhelm, K. Rezwan, Tailoring amine functionalized hybrid ceramics to control $\mathrm{CO}_{2}$ adsorption. Chem. Eng. J. 235, 198-206 (2014)

51. M.J. Puchana-Rosero, M.A. Adebayo, E.C. Lima, F.M. Machado, P.S. Thue, J.C.P. Vaghetti, C.S. Umpierres, M. Gutterres, Microwave-assisted activated carbon obtained from the sludge of tannerytreatment effluent plant for removal of leather dyes. Colloids Surf. A 504, 105-115 (2016) 
52. F.M. Machado, C.P. Bergmann, E.C. Lima, B. Royer, F.E. de Souza, I.M. Jauris, T. Calvete, S.B. Fagan, Adsorption of reactive blue 4 dye from water solutions by carbon nanotubes: experiment and theory. Phys. Chem. Chem. Phys. 14, 11139-11153 (2012)

53. N.F. Cardoso, E.C. Lima, B. Royer, M.V. Bach, G.L. Dotto, L.A.A. Pinto, T. Calvete, Comparison of Spirulina platensis microalgae and commercial activated carbon as adsorbents for the removal of reactive red 120 dye from aqueous effluents. J. Hazard. Mater. 241-242, 146-153 (2012)

54. G.L. Dotto, E.C. Lima, L.A.A. Pinto, Biosorption of food dyes onto Spirulina platensis nanoparticles: equilibrium isotherm and thermodynamic analysis. Bioresour. Technol. 103, 123-130 (2012)

55. A. Dabrowski, Adsorption: from theory to practice. Adv. Colloid Interface Sci. 93, 135-224 (2001)

56. O. Hamdaoui, E. Naffrechoux, L. Petrier, C. Tifouti, Effects of ultrasound on adsorption-desorption of p-chlorophenol on granular activated carbon. Ultrason. Sonochem. 10, 109-114 (2003)

57. H.-M. Shen, G.-Y. Zhu, W.-B. Yu, H.-K. Wu, H.-B. Ji, H.-X. Shi, Y.-B. She, Y.-F. Zheng, Fast adsorption of p-nitrophenol from aqueous solution using cyclodextrin grafted silica gel. Appl. Surf. Sci. 356, 1155-1167 (2015)

58. S. Suresh, V.C. Srivastava, I.M. Mishra, Study of catechol and resorcinol adsorption mechanism through granular activated carbon: characterization, $\mathrm{pH}$ and kinetic study. Sep. Sci. Technol. 46, $1750-1766$ (2011)

59. Z. Rawajfih, N. Nsour, Sorption of phenol and 4-chlorophenol onto pumice treated with cationic surfactant. J. Colloid Interface Sci. 298, 39-49 (2006)

60. Q.-S. Liu, T. Zheng, P. Wang, J.-P. Jiang, N. Li, Adsorption isotherm, kinetic and mechanism studies of some substituted phenols on activated carbon fibers. Chem. Eng. J. 157, 348-356 (2010) 


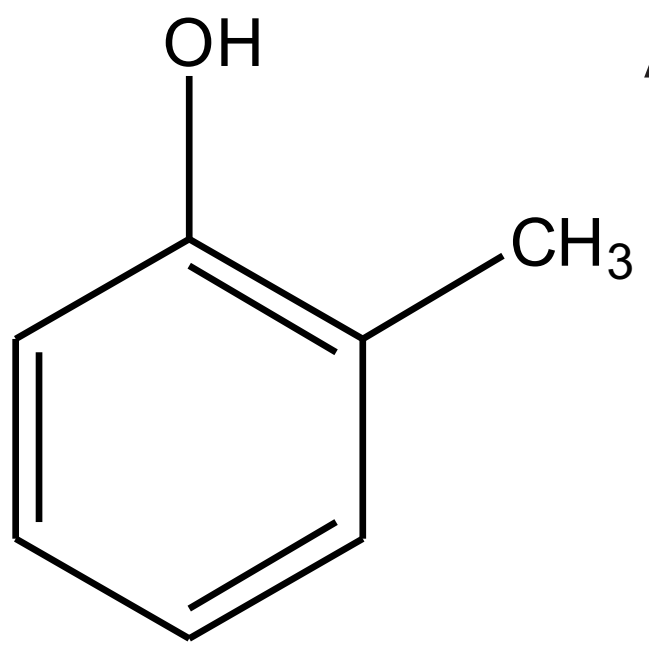

A

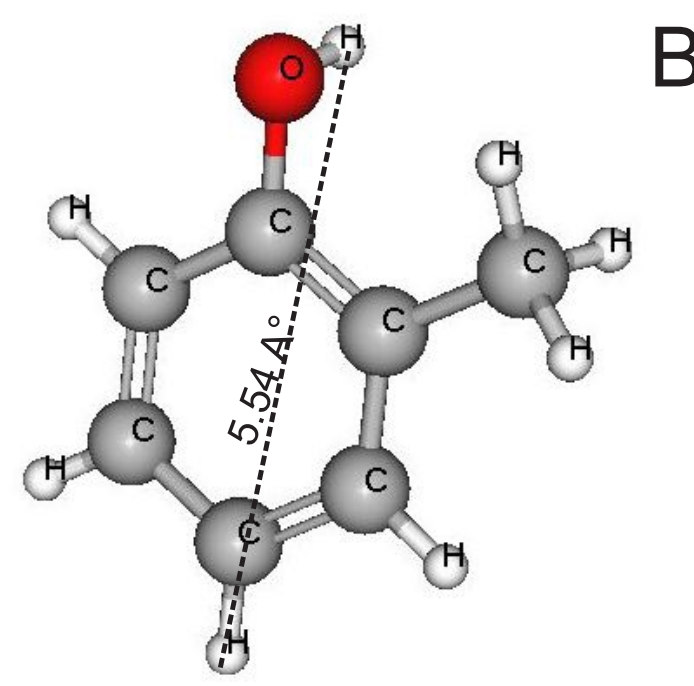

Supplementary Fig 1. A) Structural formula of o-cresol, B) Optimized three-dimensional structural formula of o-cresol. The dimensions of the chemical molecule was calculated using MarvinSketch version 16.3.14.0. Van der Waals surface area $179.01 \mathrm{~A}^{2}$ (pH 7.0); Polar surface area $20.23 \mathrm{~A}^{2}$ (pH 7.0); Dipole Moment 3.01 Debye; LogP 2.18; Log D 2.18; 

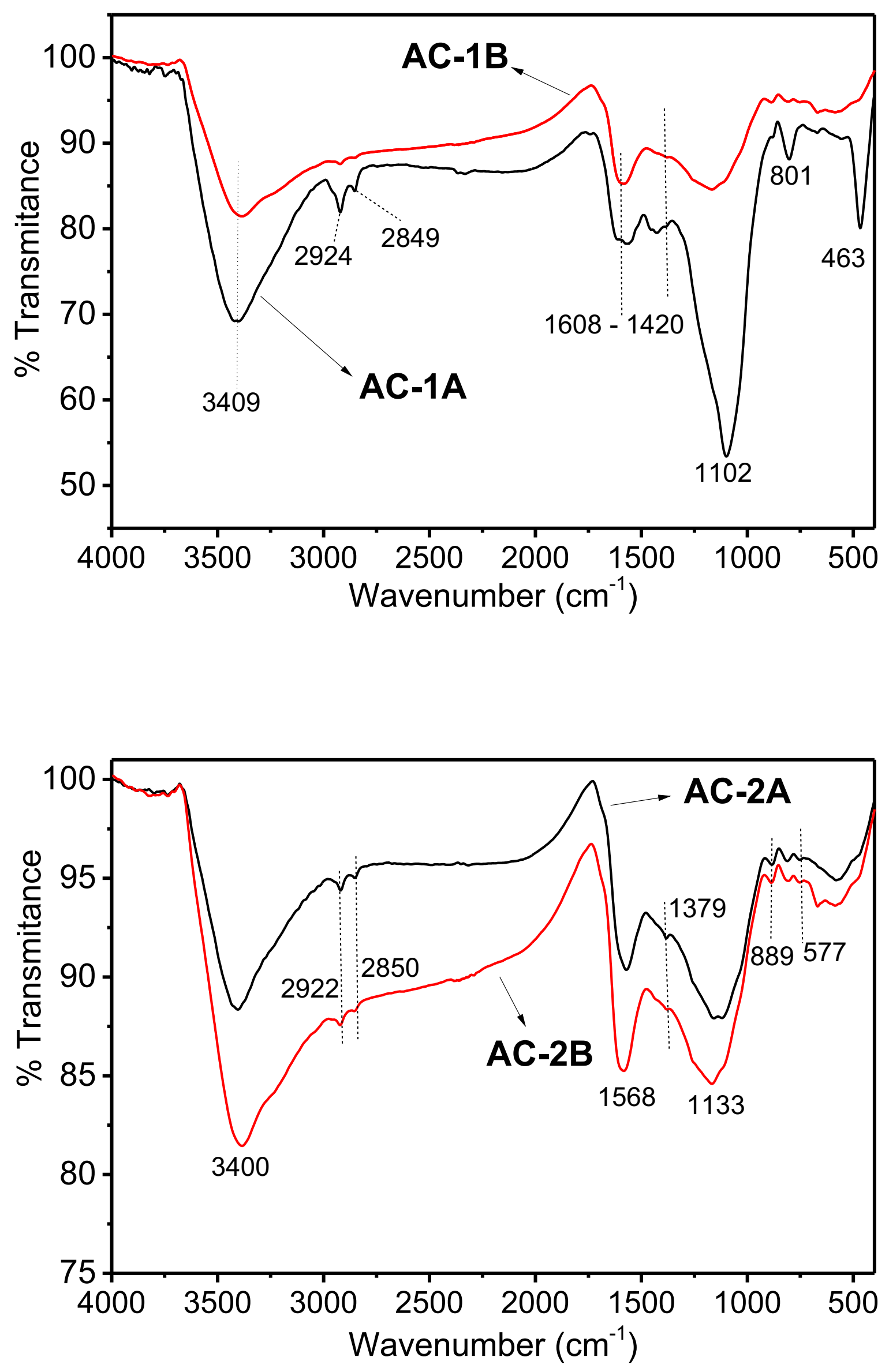

Supplementary Fig 2. FTIR spectra of activated carbons. 